\title{
Mesoscale spatial heterogeneity in chaetognath populations during upwelling abatement in the northern Benguela region
}

\author{
Alícia Duró, Josep-Maria Gili* \\ Institut de Ciències del Mar (CSIC), Passeig Joan de Borbó s/n, E-08039 Barcelona, Spain
}

\begin{abstract}
In April 1986 abatement of upwelling in the northern Benguela coincided with strong penetration by Angolan waters. The combination of these 2 phenomena generated considerable spatial heterogeneity in the physical structure of the region. In addition, the vertical location and width of the pycnocline varied over the study area. This affected the spatial distribution of the chaetognaths, shifting the axis of spatial variation from one running inshore-offshore to one running latitudinally, northsouth. A total of 19 species were present, with Sagitta setosa accounting for more than $70 \%$ of all individuals collected. Chaetognath species exhibited 4 distinct distribution patterns: some species were widely distributed throughout the entire region, though they tended to be concentrated preferentially in a certain area, while the remaining species were distributed exclusively in the southern, central, or northern parts of the region. On the whole, however, specific distribution patterns were closely related to the spatial extensions of one of 3 water masses identifiable in the region. The species in the southern part of the region had the deepest and most oceanic distribution, while the species in the northern part of the region had a more inshore distribution in the upper layers of the water column. The adaptability of chaetognaths to conditions of high turbulence like those in the pycnochne layer makes the location and strength of the pycnocline in each region one of the main factors responsible for the spatial heterogeneity observed.
\end{abstract}

KEY WORDS: Upwelling system - Pycnocline Chaetognaths Horizontal and vertical distribution . Northern Benguela South Atlantic

\section{INTRODUCTION}

Upwelling systems are unique within the world's coastal regions, in large measure because of the inputs of auxiliary energy they provide, enhancing both primary and secondary production (Margalef 1978a). The physical complex responsible for biological structure and production follows a general pattern which can with some degree of confidence be said to recur from one geographical region to another, subject of course to the peculiarities of local conditions (Barber \& Smith 1981). Processes such as divergent surface Ekman flow over convergent subsurface flow, and surface equatorward flow over a poleward subsurface flow, give rise to

•E-mail: gili@icm.csic.es a regular hydrodynamic structure during periods of upwelling activity. This system of current flow establishes a quite regular pattern of spatial distribution for the zooplankton, characterized by an inshore-oceanic gradient with a mid-shelf discontinuity at the location of the convergent surface front (e.g. Peterson et al. 1979, Hutchings 1981, Shannon \& Pillar 1986, Madhupratap et al. 1990, Pagès 1992).

The northern Benguela region is characterized by permanent coastal upwelling active all year round, with peak activity from October to December and low intensity in July and August (Shannon 1985). The location of the areas of most intense upwelling varies along the coast, though the major upwelling centres are located of Namibia in the vicinity of Lüderitz (26 to $\left.28^{\circ} \mathrm{S}\right)$. Walvis Bay $\left(23^{\circ} \mathrm{S}\right)$, Cape Frio $\left(18^{\circ} \mathrm{S}\right)$, and the Cunene River $\left(17^{\circ} \mathrm{S}\right)$. 
When upwelling subsides, a series of hydrographic phenomena can be observed in the northern Benguela region. The most common phenomenon is seasonal penetration by Angolan water every year. These intrusions increase the level of hydrodynamic heterogeneity, which reaches a peak in years of strong penetration by Angolan water These intrusions exert an effect on upwelling comparable to the El Niño event of Peru (Shannon et al. 1986). Such a phenomenon took place during the study period in April 1986 (Salat et al. 1992), when Angolan waters penetrated to $20-22^{\circ} \mathrm{S}$, where they formed a surface front with Benguela water. At the same time the coastal centres off Lüderitz and the Cunene River remained active, and an upwelling centre was detected 50 miles $(\sim 83 \mathrm{~km})$ off Walvis Bay, while anticyclonic eddies formed offshore in the southern half of the region as a result of the abatement of upwelling (Boyd et al. 1987, Salat et al. 1992). During that same period the northern Benguela region was segregated from the rest of the system by an offshore convergence located slightly south of Lüderitz (Boyd \& Agenbag 1985).

Earlier work carried out in the region showed that the spatiotemporal distribution of the zooplankton (Venter 1969, Barange 1990, Olivar \& Barange 1990), and the gelatinous zooplankton in particular (Pagès \& Gili 1991, Pagès 1992), closely mirrored the mesoscale dynamics of water masses in the region. The complex hydrodynamic situation brought about by the abatement of upwelling may give rise to a highly heterogeneous zooplankton distribution. This may take the form of a switch in the axis of the spatial variability of the zooplankton from inshore-offshore during active upwelling to north-south when upwelling abates. The combined action of the series of local hydrographic phenomena referred to above all along the coast of Namibia may give rise to spatial distributions that differ from the distribution that could otherwise be expected in the region under typical conditions of upwelling The main objective of the present paper is to analyse a particular zooplankton distribution pattern and the shift in the main axis of spatial variability by examining in detail the horizontal and vertical distribution of chaetognaths in the northern Benguela.

\section{MATERIALS AND METHODS}

The samples considered in this study were collected on the Spanish-Namibian Environment Cruise, SNEC Il, carried out over the continental shelf off Namibia from 10 to 23 April 1986. A total of 23 stations located on 4 transects (Fig. 1) off the Cunene River ( $17^{\circ} 30^{\prime} \mathrm{S}$ ). Möwe Point $\left(20^{\circ} \mathrm{S}\right)$, Walvis Bay $\left(23^{\circ} \mathrm{S}\right)$, and Lüderitz

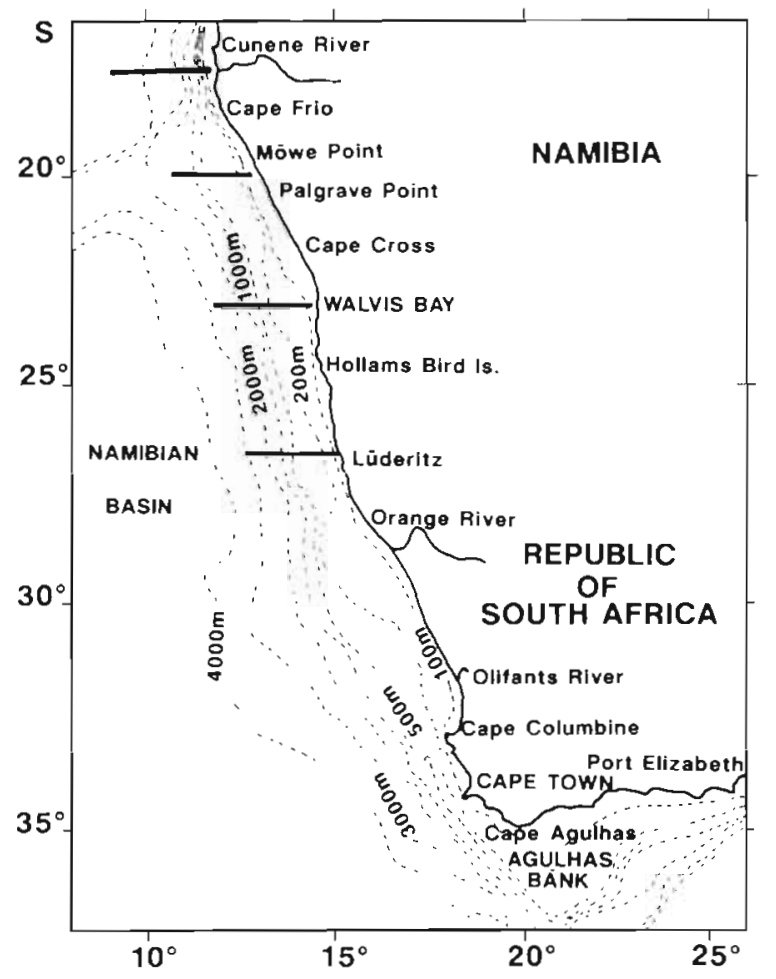

Fig 1 Study area and the 4 transects sampled during the SNEC Il cruise in the northern Benguela region

$\left(26^{\circ} \mathrm{S}\right)$ were occupied. Samples were taken both in daytime and at night, with a view to analysing possible vertical migrations. At each station temperature and salinity data were collected in the upper $200 \mathrm{~m}$ at $5 \mathrm{~m}$ depth ranges by means of a calibrated CTD probe, with simultaneous sampling of the water column at various depths using a rosette system. CTD casts were carried out in conjunction with the zooplankton samples.

Zooplankton samples were collected using a multiple opening and closing rectangular midwater trawl (RMT) $1 \times 6$ net (mesh size $200 \mu \mathrm{m}$ ). The depths of the strata varied slightly at each station according to hydrographic conditions. Sampling tows were oblique, with a mean towing speed of $0.35 \mathrm{~m} \mathrm{~s}^{-1}$ The strata comprised: (1) above the pycnocline, (2) within the pycnocline, (3) between 30 and $60 \mathrm{~m}$ below the pycnocline, and (4) from this latter depth to $200 \mathrm{~m}$ at oceanic stations or to $20 \mathrm{~m}$ above the bottom at the inshoremost stations, where bottom depth was less than $200 \mathrm{~m}$. Flow was estimated by means of a calibrated digital flowmeter mounted centrally in the mouth of each net. All zooplankton were preserved in borax-buffered $5 \%$ formalin. All individuals in the total volume of each sample collected were identified to species level and counted. However, in several samples in which extremely large numbers of individuals were captured, 
counts were made from subsamples to a maximum dilution of $1 / 8$ of total sample volume.

The individuals collected were classified in one of 3 developmental stages based on gonadal development according to Zo (1973). Stage I individuals had no visible gonads. Stage II individuals had well-developed gonads and ovaries with immature oocytes that varied in size. Stage IIl individuals presented 1 or more mature ova in the ovaries. The results were standardized to number of individuals $1000 \mathrm{~m}^{-3}$. The plots of the vertical distributions were prepared using the SURFER 5.0 computer program (Surface Mapping System ${ }^{\circ}$ 1993-1994, Golden Software, Inc., Golden, CO, USA).

Weighted mean depth was calculated using the equation WMD $=\sum\left(n_{i} \times d_{i}\right) / N($ Pearre 1973) to define the depth stratum in the water column where the core population of each species was located. In the equation, $d_{i}$ is the depth of sample $i, n_{1}$ is the number of individuals collected in sample $i$, and $N$ is the sum of all individuals collected in all the samples taken in all the depth strata. WMD values for daytime and nighttime for each species were compared using a Mann-Whitney non-parametric $U$-test, because the values were not normally distributed. Principal component analysis (PCA) was applied to the species abundance matrix, which included all the species identified, in an endeavour to obtain an objective picture of which of the 3 axes of spatial variability (inshore-offshore, latitudinal, and vertical) best explained the distribution observed. The PCA was run using the interspecific correlation matrix.

\section{RESULTS}

The hydrographic features in the region during the SNEC II survey have been described by Boyd et al. (1987) and Salat et al. (1992). They reported 3 large water masses: Angolan waters penetrating into the region down to $22^{\circ} \mathrm{S}$ from the north; oceanic waters along the entire region; and most importantly, waters associated with Benguela upwelling presenting the typical characteristics of South Atlantic Central Water (SACW) in the central, southern, and inshoremost regions in the north. Figs. 2 \& 3 depict the temperature and salinity profiles along the 4 transects sampled.

Cunene River. The Angolan water formed a surface layer from the open sea to around 30 miles $(\sim 50 \mathrm{~km})$ offshore, where it formed a front separating the upwelled water near the coast. The intrusions of Angolan water strengthened an already significant pycnocline located at a depth of around $50 \mathrm{~m}$ (discerned more readily from the density distribution).

Möwe Point. Upwelled water was located close inshore and at a depth of around $100 \mathrm{~m}$ at the oceanic stations. The surface layer along nearly the entire tran-
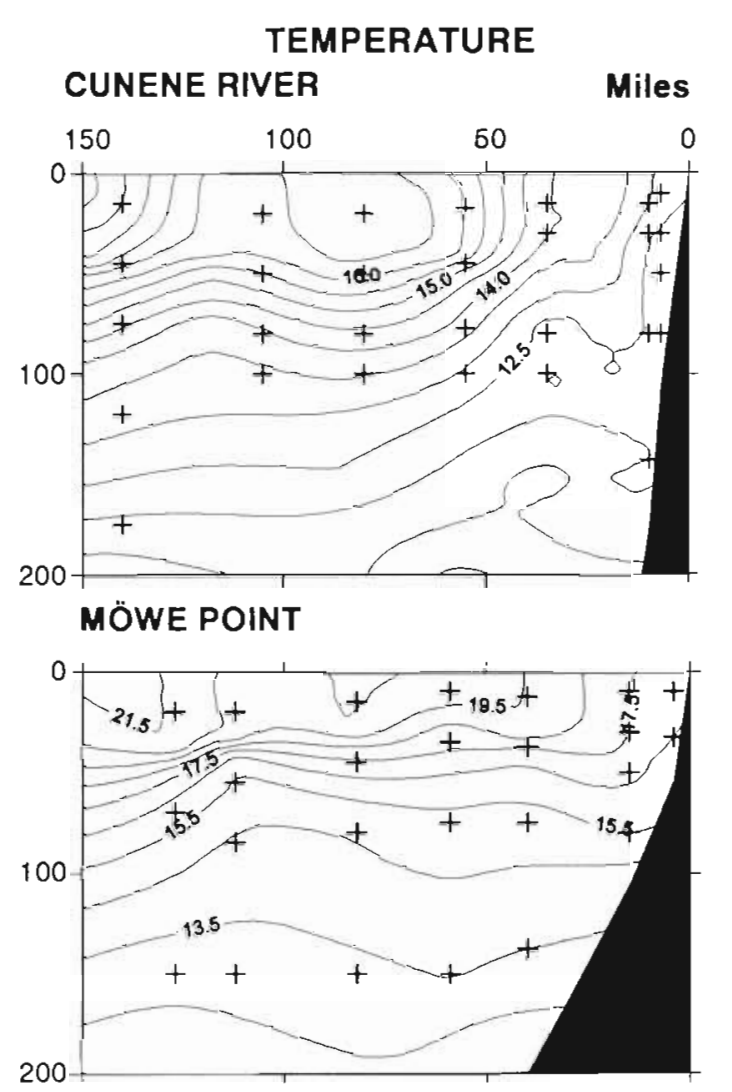

WALVIS BAY
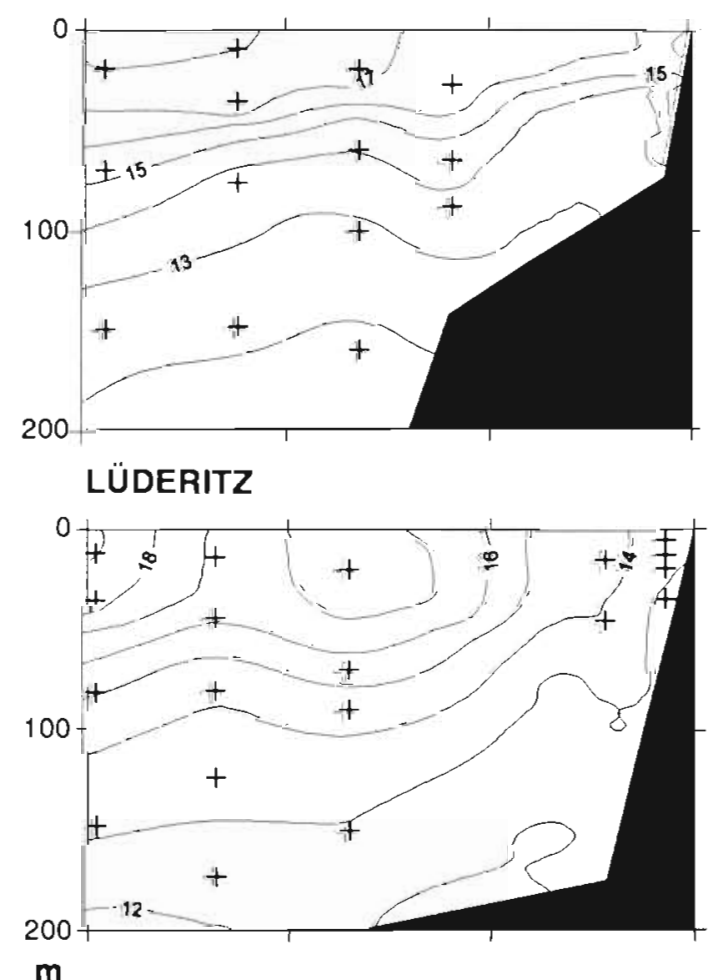

Fig. 2. Temperature profiles at the 4 transects sampled during the SNEC II cruise (see Fig. 1). Each cross is located at the middle of the upper and lower sample depth range 


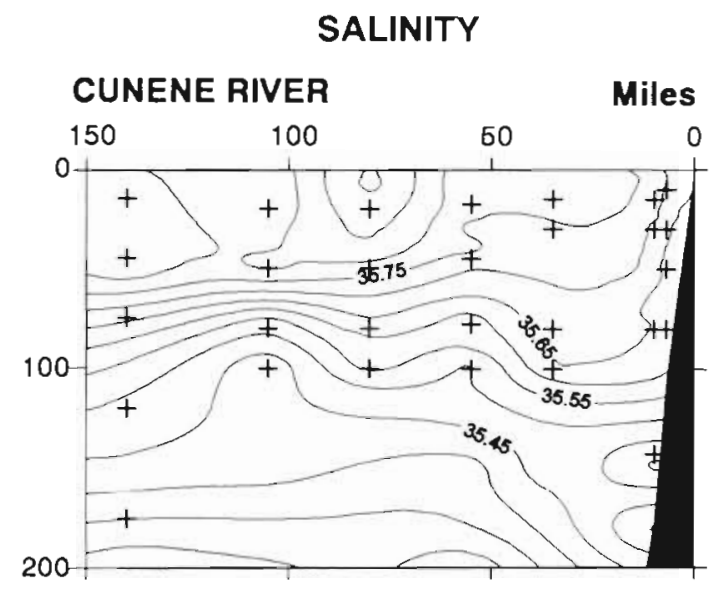

MÖWE POINT

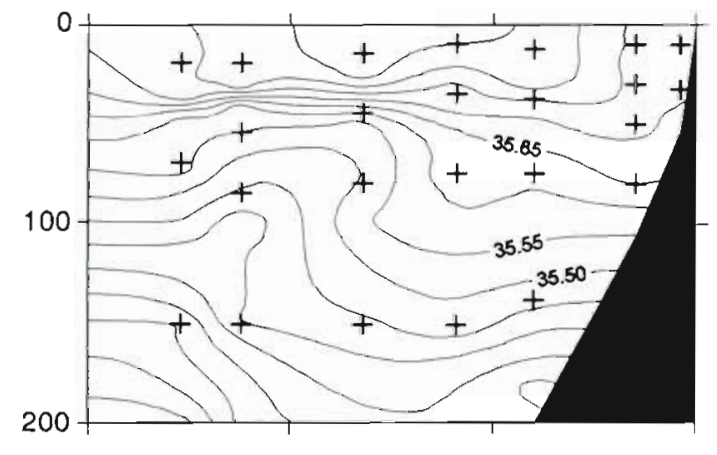

\section{WALVIS BAY}

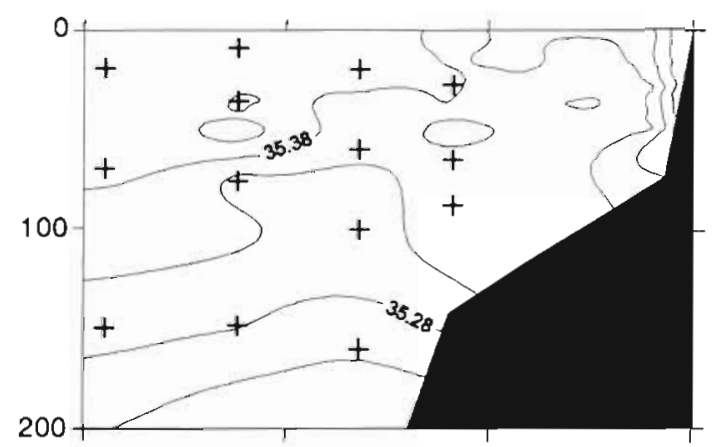

LÜDERITZ

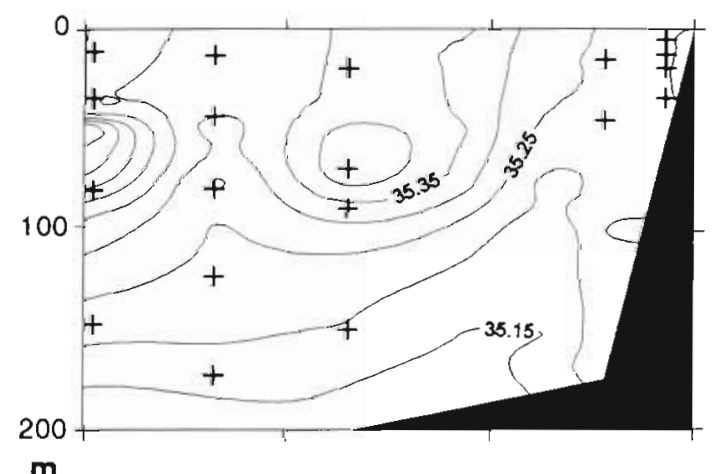

m

Fig. 3. Salinity profiles at the 4 transects sampled during the SNEC II cruise (see Fig. 1). Each cross ls located at the middle of the upper and lower sample depth range sect consisted of warm Angolan water which formed a strong pycnocline at a depth of around $50 \mathrm{~m}$. This transect was located at the southern edge of the region where the Angolan and Benguelan waters met.

Walvis Bay. Upwelled water was located out to a distance of around 30 miles $(-50 \mathrm{~km})$ offshore. Oceanic water was recorded around 120 miles $(200 \mathrm{~km})$ offshore. A convergence zone formed around 60 miles $(100 \mathrm{~km})$ offshore, where the upwelled water sank and according to Salat et al. (1992) was confined by the effect of an anticyclonic eddy that formed in the zone.

Lüderitz. The situation was typical of coastal upwelling, with cold upwelled water drifting out towards the open ocean to around 60 miles $(100 \mathrm{~km})$ offshore. From that point on out to the open sea there was a thermal discontinuity that gave rise to a pycnocline at a depth of around $50 \mathrm{~m}$. Oceanic water was recorded at around 130 miles $(-210 \mathrm{~km})$ offshore.

A total of 19 species of chaetognaths were identified (Table 1). All 3 of the maturity stages described above were not always captured for all of the species. No adults were found for Krohnitta pacifica, Sagitta hexaptera, S. lyra, and S. maxima, probably because they were located at depths greater than $200 \mathrm{~m}$, the deepest limit to sampling in this study (Alvariño 1969). Adult stages were collected for 4 species in the Serratodentata group ( $S$. bierii, $S$. pacifica, $S$. serratodentata, $S$. tasmanica), but Stages I and II could not be differentiated; hence, all the Stage I and II individuals were pooled together in the results (see Table 1). Identification was not possible because the location and shape of fins, mandatory diagnostic characters for differentiating the juveniles of these species (Grant 1967), were not clearly discernible in the preserved material. In any event, since over $90 \%$ of the adult specimens of the 4 species in the group belonged to S. tasmanica, we consider it likely that the juveniles identified belonged to that species as well.

Five of the 19 species identified accounted for $97.9 \%$ of the total number of individuals collected. Sagitta setosa was the most abundant species $(71.3 \%$ of the totall, with maximum densities in the vicinity of Lüderitz, where densities for Stage I juveniles were greater than 30 ind $\mathrm{m}^{-3}$ and those for adults greater than 8 ind. $\mathrm{m}^{-3}$. S. enflata was the second most abundant species in the region (6.1\% of the total), with densities of 1.2 adult ind $\mathrm{m}^{-3}$ and 1.3 Stage I juvenile ind. $\mathrm{m}^{-3}$ in the surface layer off Möwe Point. S. minima was another abundant species in Möwe Bay $15.1 \%$ of the total), with densities of 1.2 adult ind. $\mathrm{m}^{-3}$ and 0.7 Stage II juvenile ind $\mathrm{m}^{-3}$.

Sagitta tasmanica $(3.4 \%$ of the total) was the next most abundant species, with densities of 2.6 adult ind. $\mathrm{m}^{-3}$ in the vicinity of Walvis Bay. Juveniles belonging to the Serratodentata group represented $10.5 \%$ of the 
Table 1 Mean abundance and standard deviation values for the different species and maturity stages (ind. $1000 \mathrm{~m}{ }^{3}$ on the 4 transects considered (see Fig. 1)

\begin{tabular}{|c|c|c|c|c|c|c|c|c|}
\hline & \multicolumn{2}{|c|}{ Lüderitz } & \multicolumn{2}{|c|}{ Walvis Bay } & \multicolumn{2}{|c|}{ Möwe Point } & \multicolumn{2}{|c|}{ Cunene River } \\
\hline & Mean & SD & Mean & SD & Mean & $\mathrm{SD}$ & Nean & $\mathrm{SD}$ \\
\hline Eukrohnia hamata I & - & - & 38.72 & 107.00 & 13.54 & 67.68 & - & - \\
\hline Eukrohnia hamata II & - & - & 39.04 & 79.05 & 6.92 & 34.59 & - & - \\
\hline Eukrohnia hamata III & - & - & 36.03 & 106.26 & 8.79 & 42.30 & - & - \\
\hline Krohnutta subtilis I & - & - & - & - & - & - & 0.67 & 2.66 \\
\hline Krohnitta subtilis III & - & - & - & - & - & - & 0.94 & 2.36 \\
\hline Krohnitta pacifica l & - & - & 4.31 & 11.27 & - & - & - & - \\
\hline Krohnitta pacifica Il & - & - & 0.47 & 1.81 & - & - & - & - \\
\hline Pterosagitta draco I & 0.75 & 3.19 & - & - & 1.81 & 6.29 & 3.29 & 16.32 \\
\hline Pterosagitta draco ll & 11.93 & 30.79 & - & - & 2.60 & 6.64 & 3.29 & 13.81 \\
\hline Pterosagitta draco III & 19.21 & 37.30 & 3.76 & 14.56 & 5.25 & 14.44 & 3.25 & 12.35 \\
\hline Sagitta decipiens I & 45.37 & 80.11 & 69.61 & 181.81 & 1.70 & 8.50 & 59.31 & 137.17 \\
\hline Sagitta decipiens II & 56.14 & 82.51 & 56.91 & 124.61 & 2.34 & 11.69 & 17.41 & 33.10 \\
\hline Sagitta deciprens III & 42.28 & 60.41 & 29.70 & 67.50 & 1.70 & 8.50 & 20.05 & 41.12 \\
\hline Sagitta enflata I & - & - & - & - & 1317.84 & 2441.42 & 553.06 & 1106.95 \\
\hline Sagitta enflata II & - & - & - & - & 693.38 & 1181.91 & 273.17 & 449.98 \\
\hline Sagitta enflata III & - & - & - & - & 1232.19 & 3725.04 & 197.52 & 420.49 \\
\hline Sagitta friderici I & - & - & - & - & - & - & 0.56 & 2.97 \\
\hline Sagitta friderici II & - & - & - & - & - & - & 1.40 & 7.42 \\
\hline Sagitta friderici III & - & - & - & - & - & - & 25.64 & 72.40 \\
\hline Sagitta hexaptera I & - & - & - & - & 1.48 & 5.17 & 0.82 & 3.32 \\
\hline Sagitta hexaptera II & - & - & 0.55 & 1.48 & 4.06 & 13.58 & 10.02 & 19.40 \\
\hline Sagitta lyra I & 45.88 & 78.97 & 112.48 & 179.23 & 159.66 & 270.51 & 449.66 & 756.95 \\
\hline Sagitta lyra Il & 44.24 & 73.63 & 88.64 & 139.74 & 71.43 & 105.17 & 152.15 & 167.98 \\
\hline Sagitta marri 1 & - & - & 21.60 & 60.78 & - & - & - & - \\
\hline Sagitta Marri II & - & - & 15.66 & 43.80 & - & - & - & - \\
\hline Sagitta marri IlI & - & - & 10.96 & 27.35 & - & - & - & - \\
\hline Sagitta maxima I & 1.57 & 6.67 & - & - & - & - & - & - \\
\hline Sagutta maxima II & 2.75 & 8.02 & .- & - & - & - & .. & - \\
\hline Sagutta minıma I & 29.11 & 84.66 & 5.12 & 14.70 & 401.49 & 980.60 & 70.10 & 119.28 \\
\hline Sagitta minima II & 81.01 & 157.61 & 13.81 & 23.89 & 718.31 & 1632.54 & 198.68 & 427.76 \\
\hline Sagitta munıma III & 1.50 .75 & 292.45 & 33.29 & 58.88 & 1272.55 & 2934.20 & 705.59 & 1305.75 \\
\hline Sagitta planctonis I & - & - & - & - & 215.90 & 645.72 & 3.26 & 12.86 \\
\hline Sagitta planctonis II & 0.49 & 2.07 & 2.91 & 6.54 & 71.14 & 308.73 & 2.03 & 6.67 \\
\hline Sagitta planctonis III & 0.26 & 1.10 & 0.63 & 2.43 & 23.86 & 75.07 & 1.59 & 5.85 \\
\hline Sagitta robusta I & - & - & - & - & 96.14 & 325.35 & 129.10 & 276.11 \\
\hline Sagitta robusta II & - & - & - & - & 49.72 & 165.04 & 62.84 & 125.42 \\
\hline Sagitta robusta III & - & - & - & - & 11.59 & 50.86 & 29.74 & 61.27 \\
\hline Serratodentata group I & 56.63 & 95.81 & 3391.77 & 5337.52 & 1223.96 & 1291.31 & 1180.41 & 1716.55 \\
\hline Serratodentata group II & 74.16 & 119.21 & 2551.60 & 3898.08 & 548.92 & 726.68 & 519.31 & 635.23 \\
\hline Sagitta bierii [Il & - & - & - & - & - & - & 1.12 & 5.93 \\
\hline Sagitta pacifica III & 1.28 & 5.45 & - & - & - & - & - & - \\
\hline Sagitta serratodentata III & 0.75 & 3.19 & - & - & 83.63 & 226.98 & 2.28 & 5.91 \\
\hline Sagitta tasmanica lll & 296.08 & 442.94 & 2668.53 & 3401.30 & 413.54 & 659.52 & 166.65 & 262.27 \\
\hline Sagitta setosa l & 30507.21 & 75572.45 & - & - & 3060.79 & 14621.19 & 152.10 & 475.24 \\
\hline Sagitta setosa II & 23115.67 & 54745.82 & 0.31 & 1.20 & 1626.62 & 7103.96 & 210.37 & 601.67 \\
\hline Sagitta setosa III & 8001.28 & 20178.53 & 0.31 & 1.20 & 353.23 & 1568.20 & 258.30 & 754.29 \\
\hline
\end{tabular}

total. Only juvenile individuals of S. lyra $(1.5 \%$ of the total) were collected, with densities of 0.4 Stage I ind. $\mathrm{m}^{-3}$ in the vicinity of the Cunene River. Together, the remaining species did not exceed $0.6 \%$ of the total of all individuals collected.

The first PCA was carried out on all individuals (adults and juveniles combined) for each species. The plot of the first 2 axes (Fig. 4) showed that the first axis (explained variance $13.5 \%$ ) grouped the species according to latitudinal distribution. The most highly positive $f$-scores were for such species as Sagitta enflata and $S$. robusta, which were concentrated in the northernmost portion of the study area. In contrast, negative $f$-scores were for such species as $S$. setosa, $S$. maxima, S. marri, Eukrohnia hamata and Krohnitta pacifica, which were present mainly in the southernmost portion of the region or had maximum density values there. The values closest to 0 were for species distributed broadly over the entire study area, such as S. Lyra, S decipiens, S. minima and the Serratodentata 


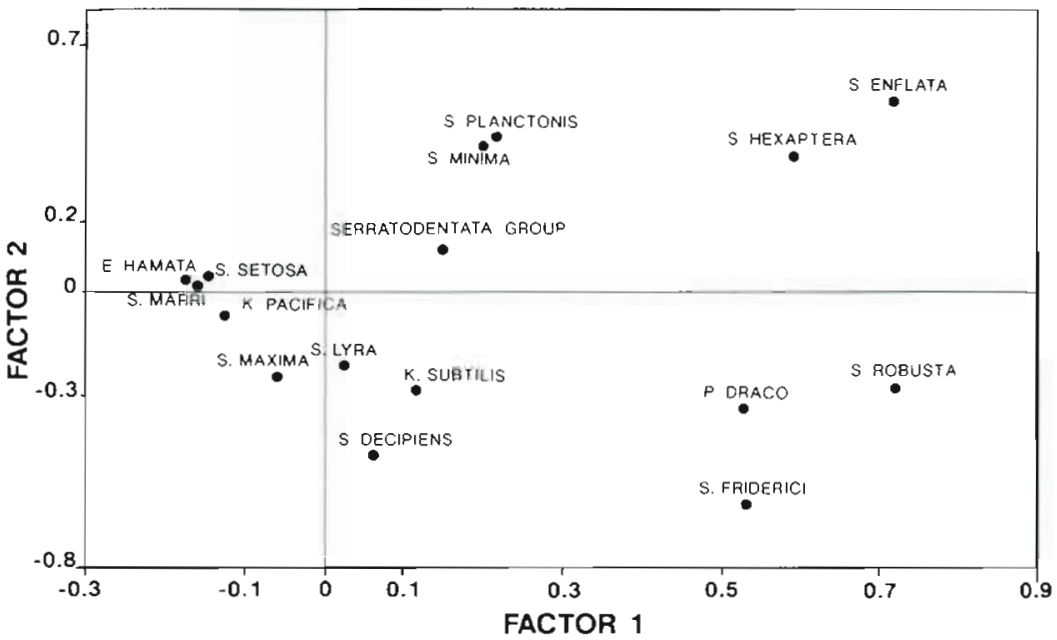

Fig. 4. Plot of the 19 species collected in the space defined by the first 2 factors of the principal component analysis (PCA). The Serratodentata group included all individuals (juveniles and adults) of the 4 species Sagitta biern, S. pacifica, S. serratodentata, and S. tasmanica. The species with the most positive $f$-score values along the first axis were concentrated in the northern part of the region, the species with the most negtive values in the south group. The second axis (explained variance 11.3\%) appeared to differentiate the species with surface distributions from those concentrated in deeper strata, but this was not entirely clear. For that reason the analysis was repeated, this time separating the adult individuals of the 4 species in the Serratodentata group, though still pooling together all the juveniles in that group, because each species seemed to be concentrated in a different location. This separation of adult Serratodentata species increased the resolution of the statistical program. The first axis in this second analysis (explained variance $13.04 \%$ ) again grouped the species latitudinally, as in the former analysis. However, this time the second axis (explained variance $11.5 \%$ ) clearly discriminated the species with deeper distributions (the more highly positive $f$-scores) such as S. lyra, $S$. pacifica, and $K$. pacifica from those with more surface distributions (the more highly negative $f$-scores) such as S. enflata and S. minima (Fig. 5). The third factor of spatial variation considered, inshore-offshore, the main axis in conditions of more active upwelling, was here the least important of the 3 .

Based on the PCA results, the species can be grouped into 4 main categories according to their latitudinal distributions: (1) species with broad distributions over the entire study area, though more abundant in either the northernmost or southernmost parts of the region; (2) species concentrated in the northernmost part of the region; (3) species concentrated in the central part of the region; and (4) species present only in the southernmost part of the region.

\section{Species with broad distributions}

Sagitta setosa was collected at the stations closest to the coast on all the transects except the one off Walvis Bay, where the species was very scarce. Both the adults (Fig 6) and the 2 juvenile stages (Figs. 7 \& 8) formed dense patches in the surface and subsurface

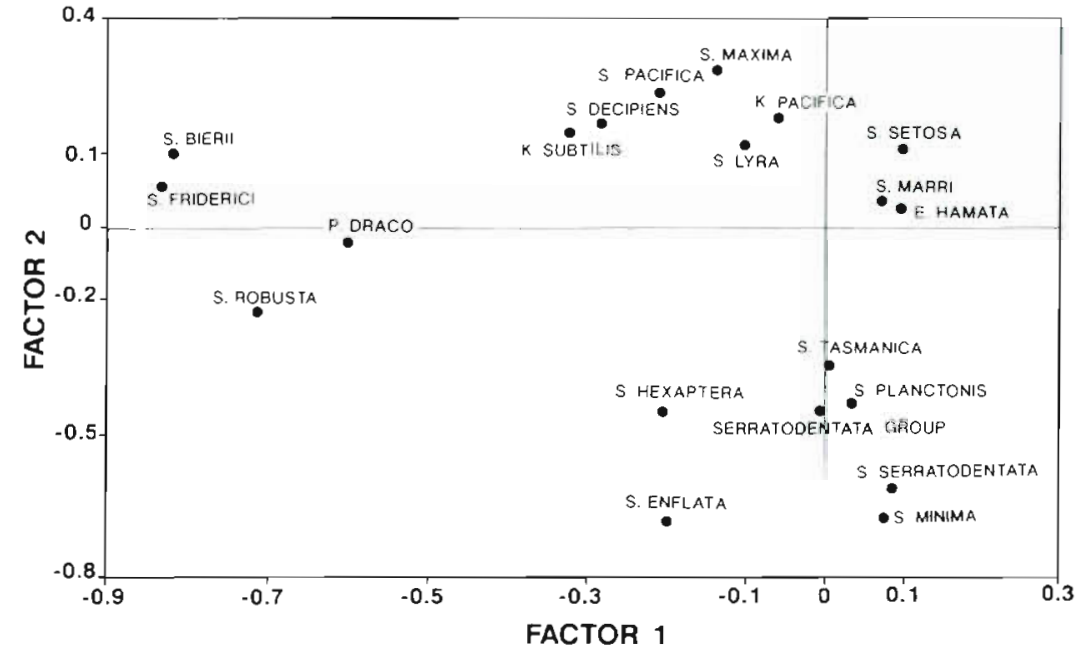

Fig. 5. Plot of the 19 species collected in the space defined by the first 2 factors of the princupal component analysis (PCA). The Serratodentata group included only the juvenile individuals of the 4 species Sagitta bierii, S pacifica, S serratodentata, and S. tasmanica. The species with the most positjve $f$-score values along the second axis were distributed mainly in the upper layers of the water column, the species with the most negative values mainly in the deeper layers 


\section{Sagitta setosa III}

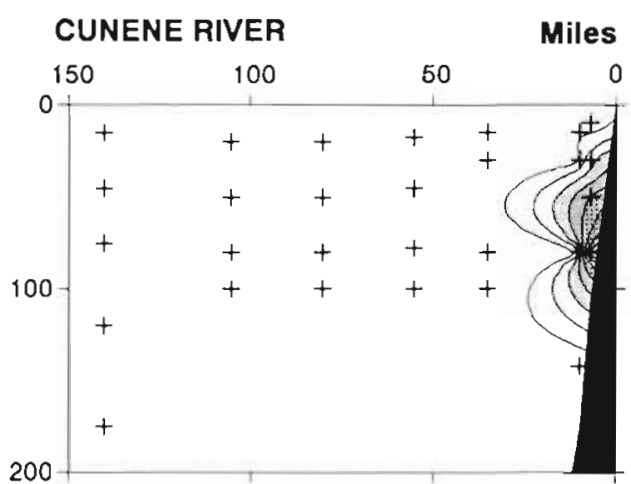

\section{MÖWE POINT}

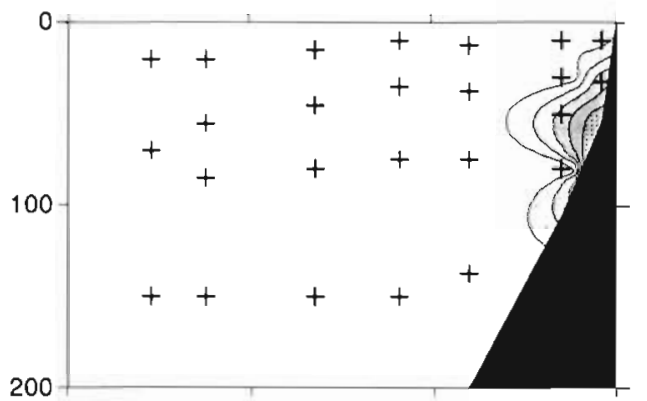

\section{WALVIS BAY}
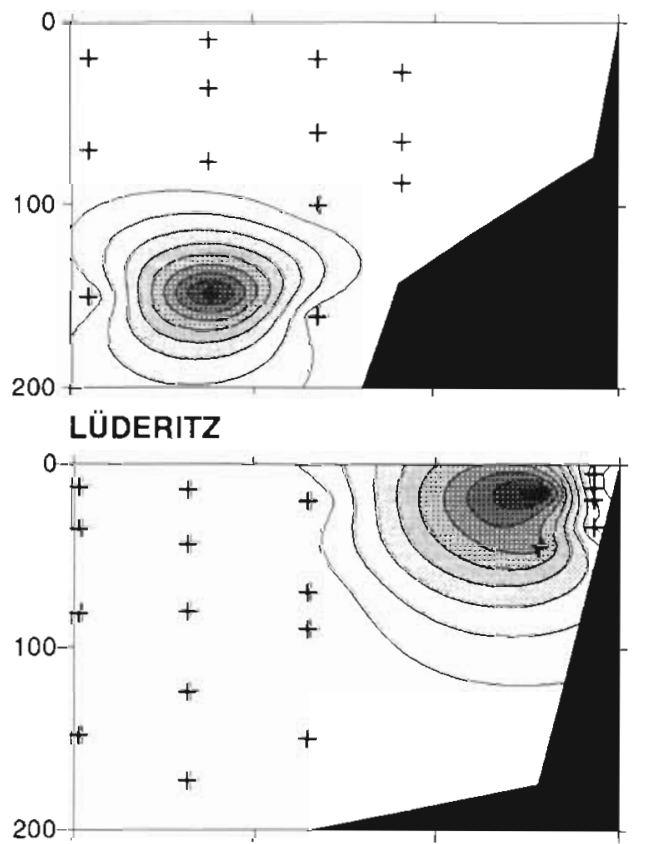

m

Fig. 6. Vertical distribution of adult Sagitta setosa on the 4 transects sampled off the Namibian coast (ind. $1000 \mathrm{~m}^{-3}$ )

layers of upwelled water inshore. The highest concentrations for all 3 developmental stages were located on the Lüderitz transect, where abundance values were at least 2 or 3 times higher than on the northern transects (Table 1). The vertical distributions for all 3 stages fol-
Sagitta setosa II
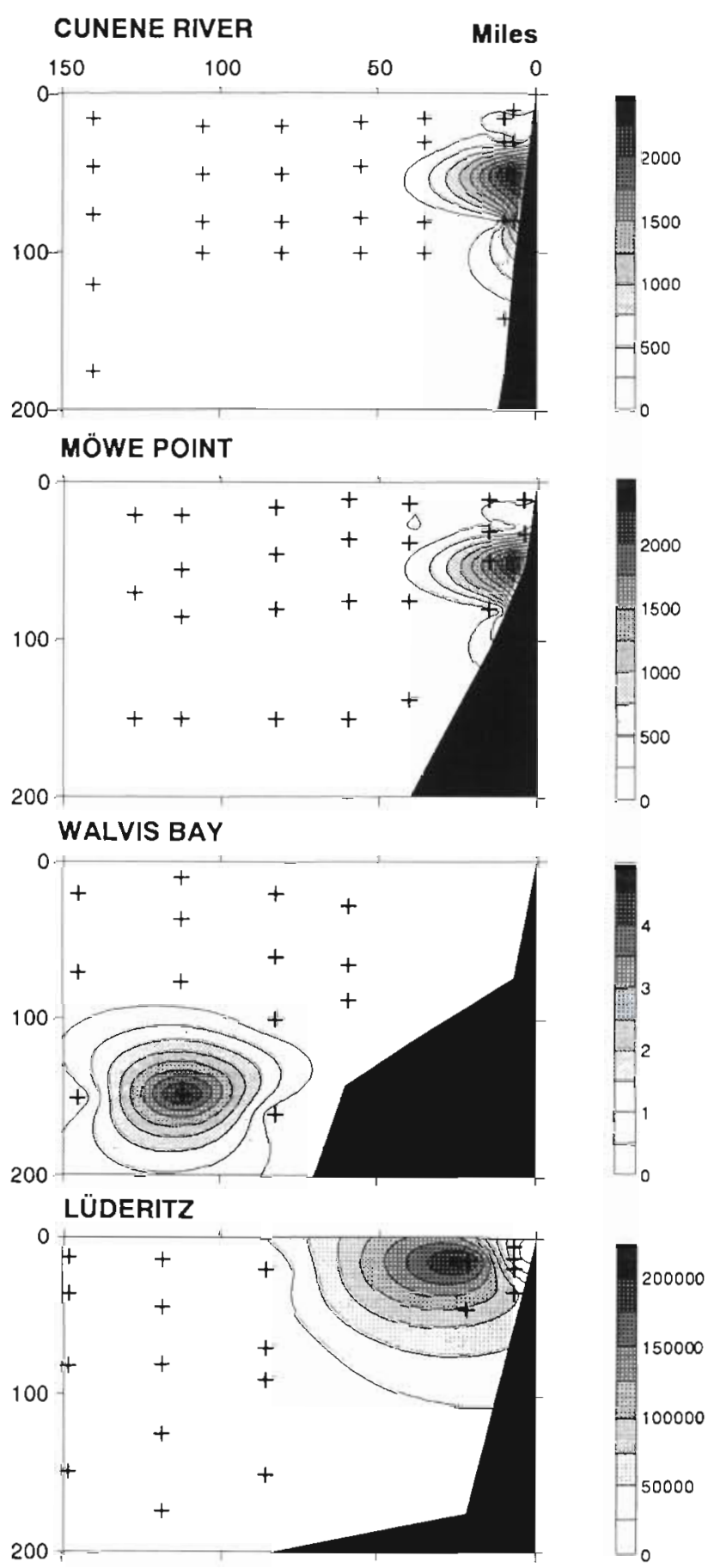

m

Fig. 7. Vertical distribution of juveniles (maturity stage II) Sagitta setosa on the 4 transects sampled off the Namibian coast (ind. $1000 \mathrm{~m}^{-3}$ )

lowed a common pattern in which they were concentrated in surface waters on the Lüderitz transect and in subsurface waters on the northern transects. Both adults and Stage II juveniles were concentrated in 


\section{Sagitta setosa I}

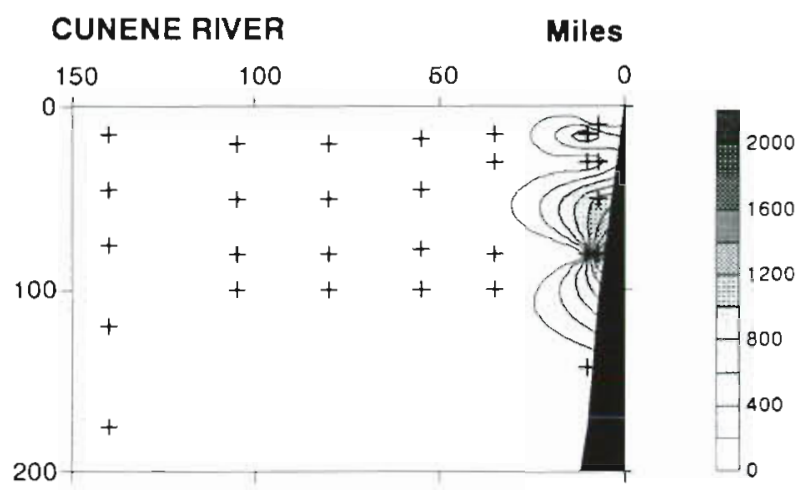

\section{MÖWE POINT}
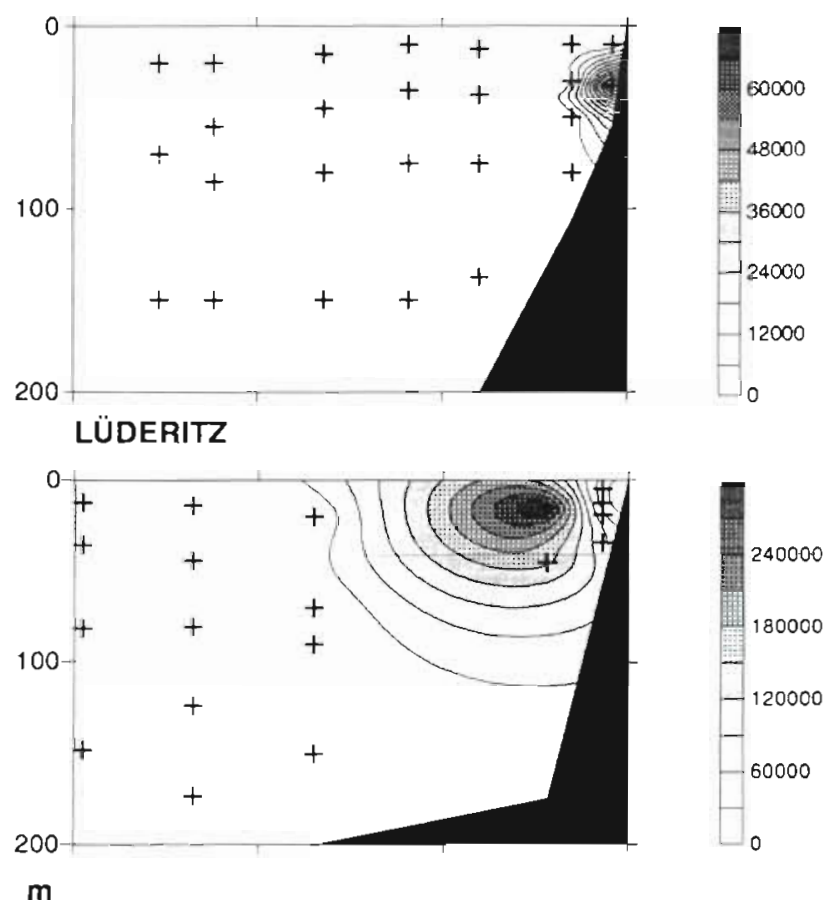

Fig. 8. Vertical distribution of juveniles (maturity stage I) Sagitta setosa on 3 of the 4 transects sampled of the Namibian coast (ind. $1000 \mathrm{~m}^{-3}$ )

deep water $(>1.00 \mathrm{~m})$ some 100 miles $(\sim 166 \mathrm{~km})$ off Walvis Bay (Figs. $6 \& 7$ ), contrasting with the findings for other transects. There were no significant variations in the nychthemeral distributions in any part of the region (Table 2 ).

Stage I juveniles of Sagitta decipiens exhibited concentrations of more than 50 ind. $1000 \mathrm{~m}^{-3}$ along all the transects except the one off Möwe Point. Stage II juveniles and adults followed similar patterns, though concentrations for adults were lower (Table 1). Juveniles of both stages were present in the vicinity of the pycnocline off Lüderitz but below that layer in the other 3 areas studied (Table 2). In contrast, adults were always located below the pycnocline. All 3 stages were located at deeper depths off Möwe Point. Distinct nychthemeral migrations by juveniles were recorded within the entire pycnocline in the north; the migrations were somewhat weaker in the south (Table 2).

The pattern for Pterosagitta draco was similar to that for Sagitta decipiens, but with appreciably lower densities (Table 1) and a tendency towards greater abundance in the south. Only juveniles were collected from surface waters, and migrations were recorded for Stage II juveniles off Möwe Point (Table 2). Some adult $S$. serratodentata were present in both the north and the south of the region and were most abundant in the surface waters on the northern transects, where they carried out migrations above the pycnocline (Table 2).

The abundance of Stage I and II juveniles of Sagitta lyra increased progressively from south to north (Table 1), with densities of more than 449 ind. $\mathrm{m}^{-3}$ off the Cunene River. Individuals of this species were located off Miowe Point below the pycnocline and in more oceanic water on the Walvis Bay and Lüderitz transects (Figs, $9 \& 10$ ). On the northern transects the distribution. pattern was more inshore and even closer to the surface. This species carried out nychthemeral migrations in all 4 parts of the study area considered, below the pycnocline on the central transects and at the level of the pycnocline on the northern transects (Table 2).

Sagitta minima was a common species in all 4 parts of the study area, though this species' abundance was appreciably higher on the 2 northern transects (Table 1). The adults inhabited more oceanic and surface waters on the 2 southern transects, whereas on the northern transects they were concentrated more inshore, particularly in the vicinity of Möwe Point (Fig. 11). Stage I and II juveniles displayed a pattern similar to that described for the adults (Figs. 12 \& 13), though density values were lower. This species was always collected from surface waters above the pycnocline, without any apparent evidence of migrations (Table 2)

Adult Sagitta tasmanica were highly abundant off Walvis Bay, where densities attained levels of more than 2.6 ind $\mathrm{m}^{-3}$ (Table 1). Off Lüderitz the distribution of this species was subsurface (Fig. 14), changing to a broader distribution closer to the surface ranging shorewards on the northern transects. Migrations were very uncommon and always took place above or at the level of the pycnocline on the Luderitz transect. The distribution pattern for the juveniles was similar to that for the adults, but with higher density values on all 4 transects (Figs. $15 \&$ 16), assuming that $S$. tasmanica makes up most of individuals in the Serratodentata group. As in the case of the adults, they were also rather more abundant off Walvis Bay, and the distribution was somewhat more inshore and closer to the surface on the 2 northern transects. Migrations were not very pronounced and were al.ways above the pycnocline (Table 2 ). 
Table 2. Core densities (ind. $1000 \mathrm{~m}^{-3}$ ) from $200 \mathrm{~m}$ to the surface reflected by the weighted mean depth values (in $\mathrm{m}$ ) in the daytime and at night for the 19 species and maturity stages collected (significance determined by Mann-Whitney non-parametric $U$-test test: $\mathrm{p} \leq 0.01$ indicated in bold)

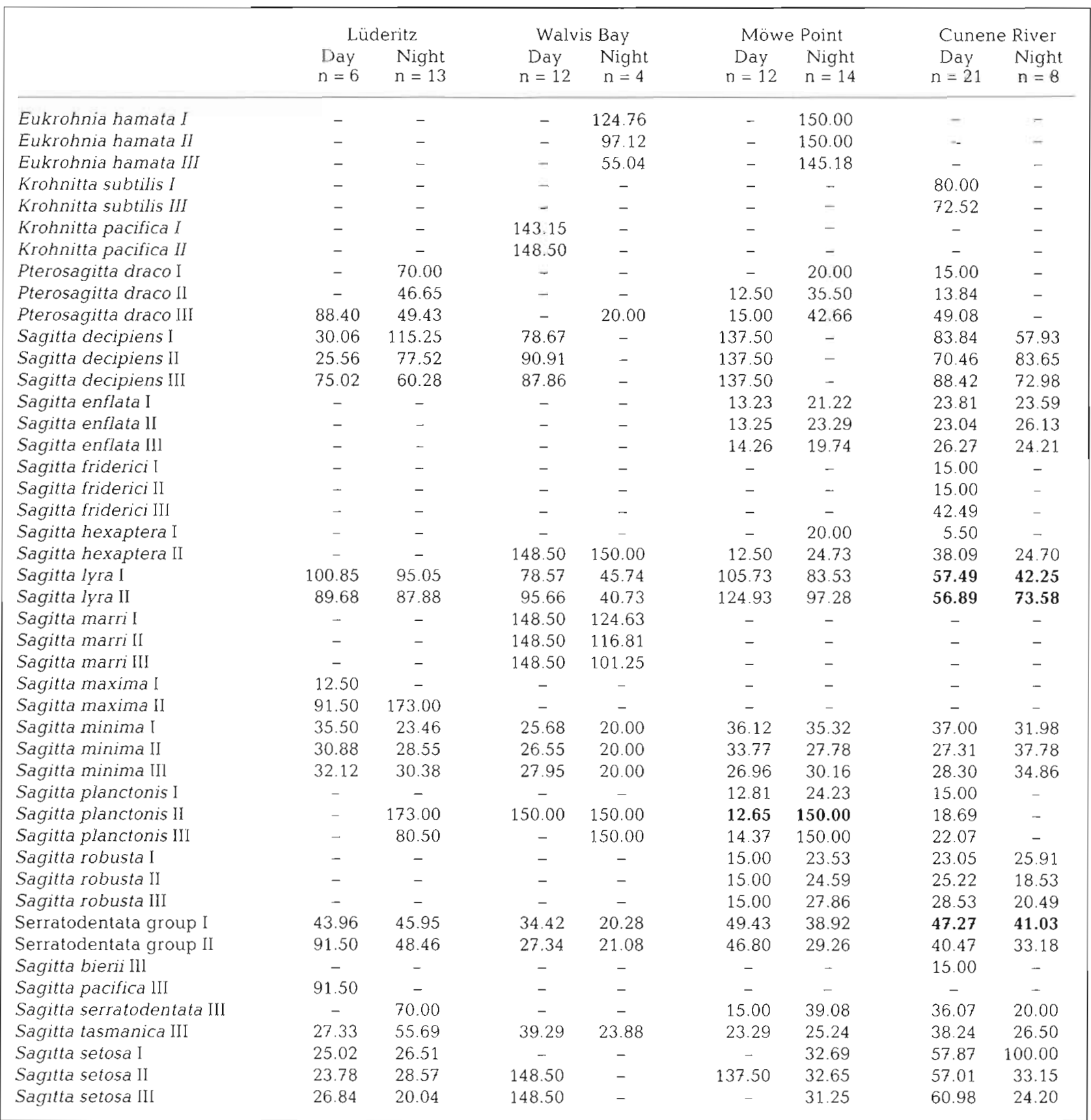

\section{Species in the northern part of the area}

Sagitta enflata adults were always associated with Angolan water, namely, they were concentrated in the surface layers on the northern transects (Fig. 17). Stage I and II juveniles ranged closer inshore than the adults, to roughly 30 miles $(50 \mathrm{~km}$ ) offshore (Figs. $18 \& 19$ ), but patches were less well defined. Adults were more abun- dant off Möwe Point, where densities were in excess 1.2 ind. $\mathrm{m}^{-3}$ (Table 1). S. robusta and $S$. hexaptera displayed distribution patterns similar to that for $S$. enflata, though they were rather less abundant (Table 1). These species differed in that the adults also appeared to carry out short migrations (Table 2). Only a few individuals of $S$. friderici and $S$. bierii were collected from surface waters on the Cunene River transect. Stage I juve- 


\section{Sagitta lyra II}
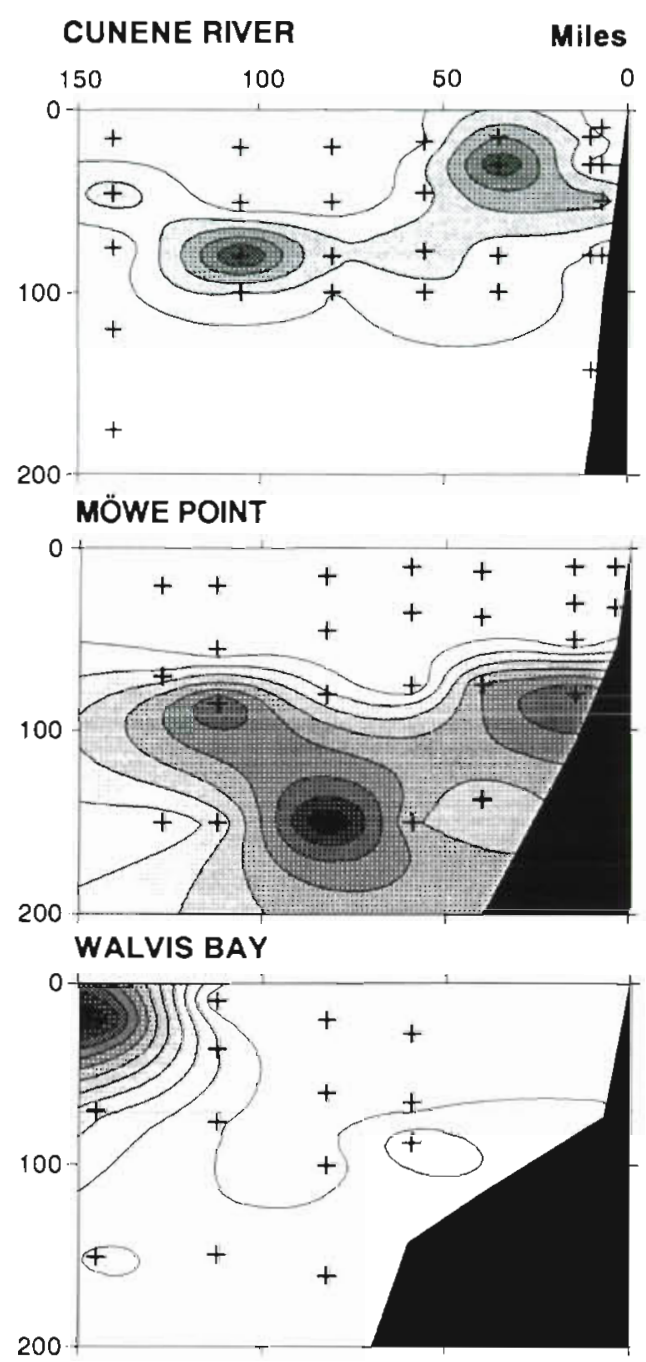

\section{LÜDERITZ}

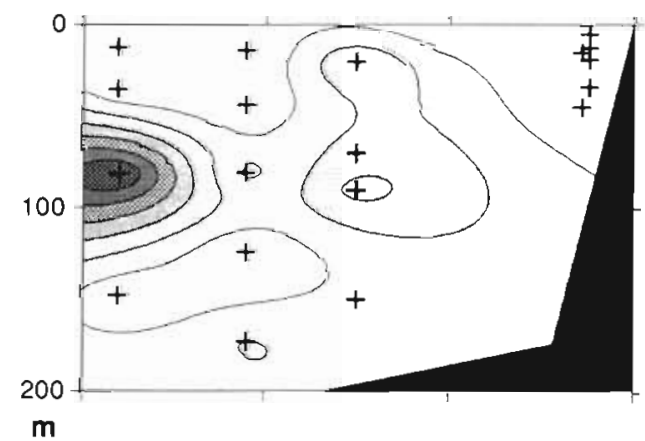

Fig. 9. Vertical distribution of juveniles (maturity stage II) Sagitta lyra on the 4 transects sampled off the Namibian coast (ind. $1000 \mathrm{~m}^{-3}$ )

niles of $S$. planctonis were found only on the 2 northern transects (Table 1), while a few Stage II juveniles and adults were collected on the other transects. Juveniles and adults of this latter species dwelled below the pycn-

\section{Sagitta lyra I}
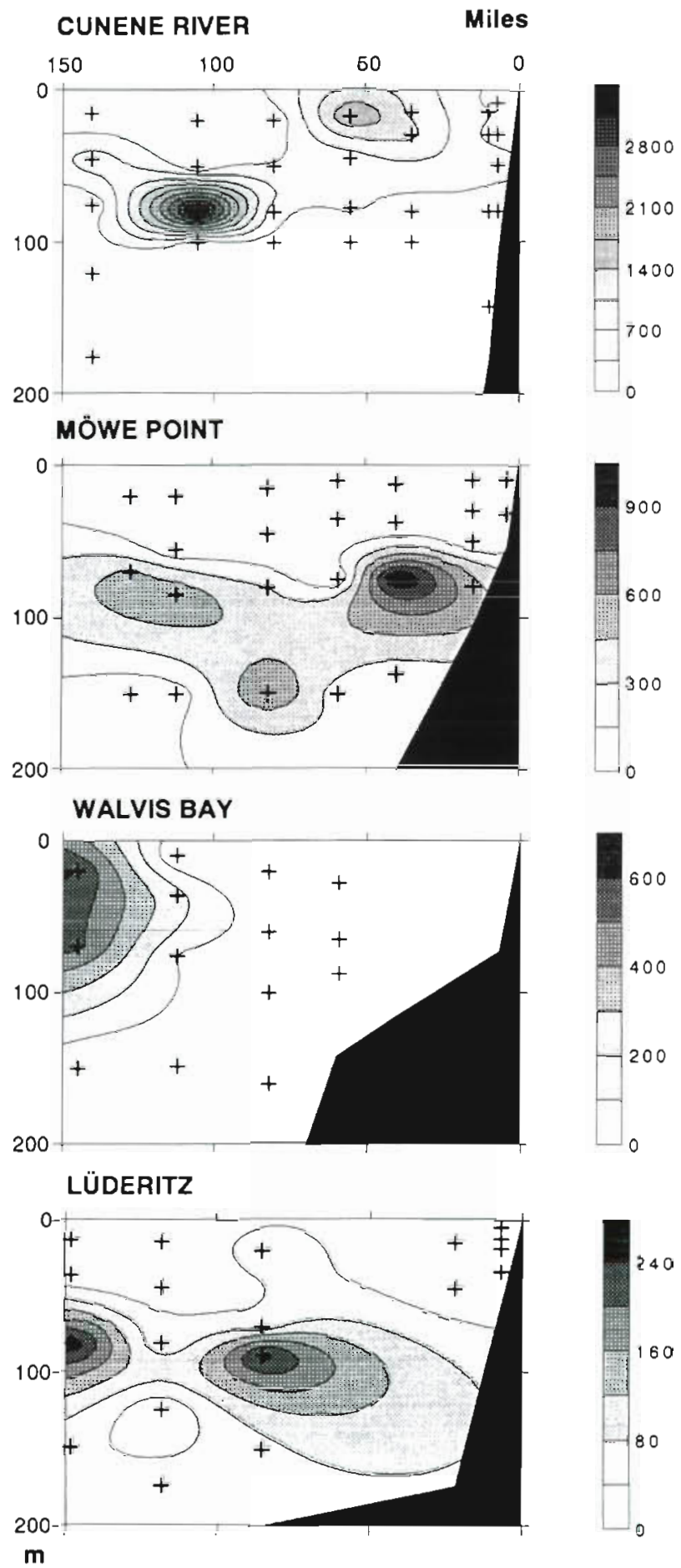

Fig. 10. Vertical distribution of juveniles (maturity stage I) Sagitta lyra on the 4 transects sampled off the Namibian coast (ind. $1000 \mathrm{~m}^{-3}$ )

ocline, and off Möwe Point they carried out large reverse migrations (Table 2). Stage I juvenile and adult Krohnitta subtilis were only present on the Cunene River transect at very low densities below the pycnocline. 
Sagitta minima III

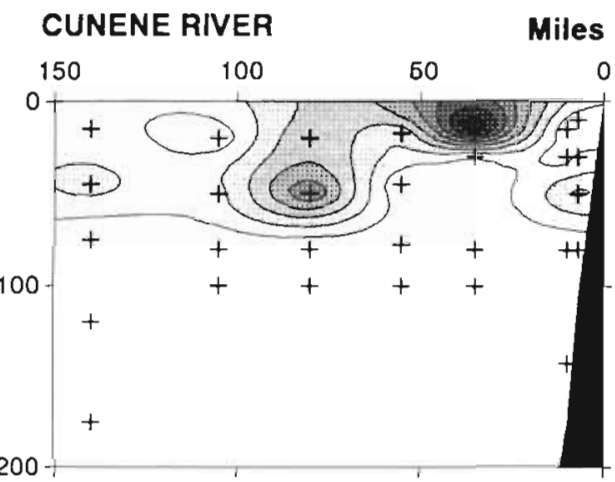

Miles

\section{MÖWE POINT}
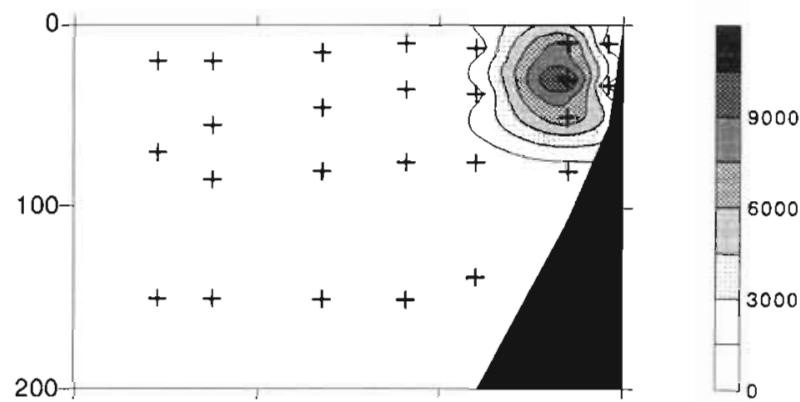

\section{WALVIS BAY}

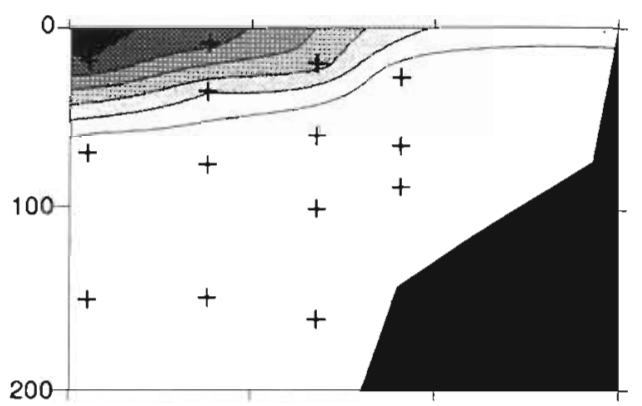

\section{LÜDERITZ}
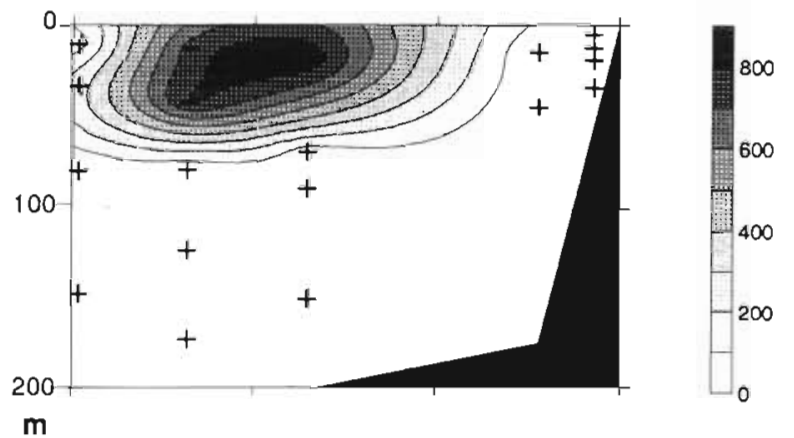

Fig. 11. Vertical distribution of adult Sagitta minima on the 4 transects sampled off the Namibian coast (ind. $1000 \mathrm{~m}^{-3}$ )

Species in the central part of the area

Adult and juvenile Sagitta marri, Krohnitta pacifica, and Eukrohnia hamata were collected only in the

\section{Sagitta minima II}
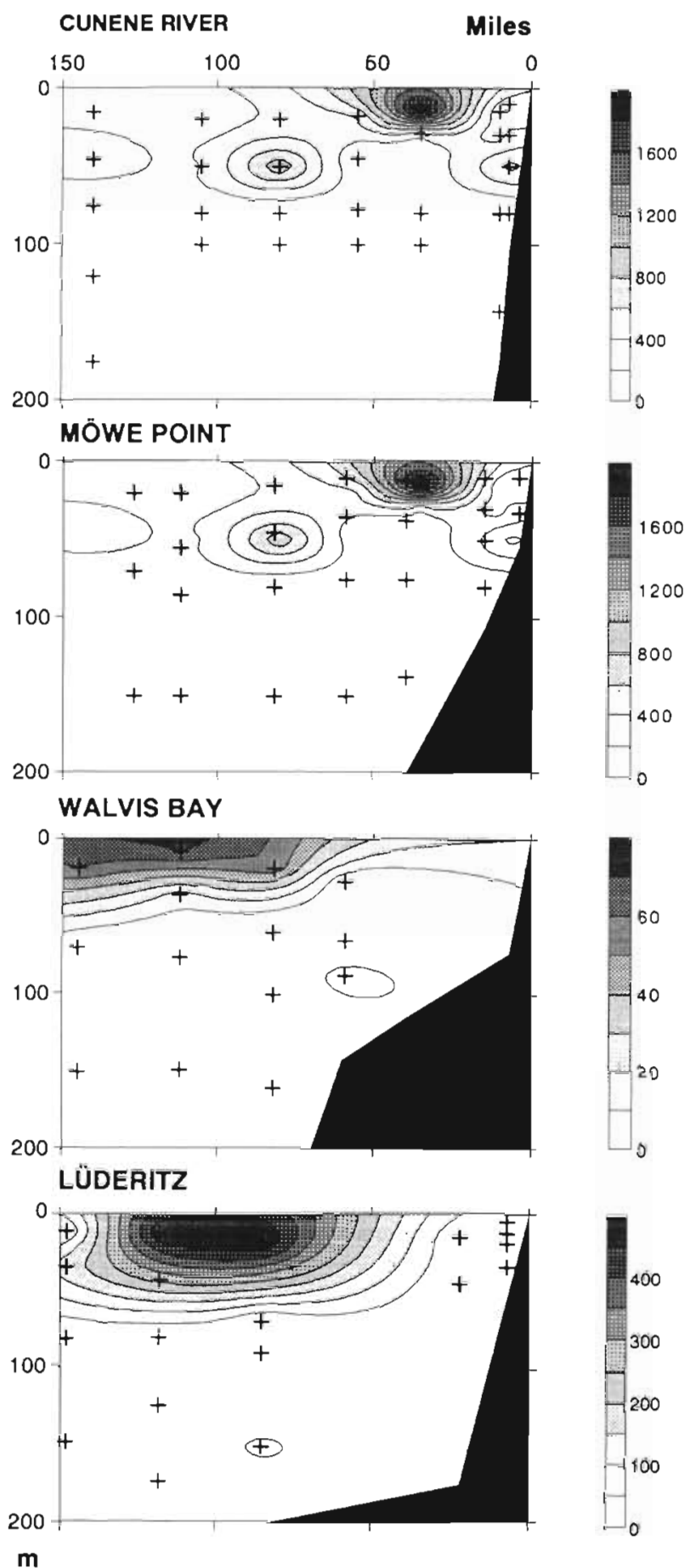

Fig. 12. Vertical distribution of juveniles (maturity stage II) Sagitta minima on the 4 transects sampled off the Namibian coast (ind. $1000 \mathrm{~m}^{-3}$ )

central part of the study area (Table 1). All specimens were collected below the pycnocline, and $S$. marri exhibited some migratory movements that in no case traversed the pycnocline (Table 2 ). 


\section{Sagitta minima I}
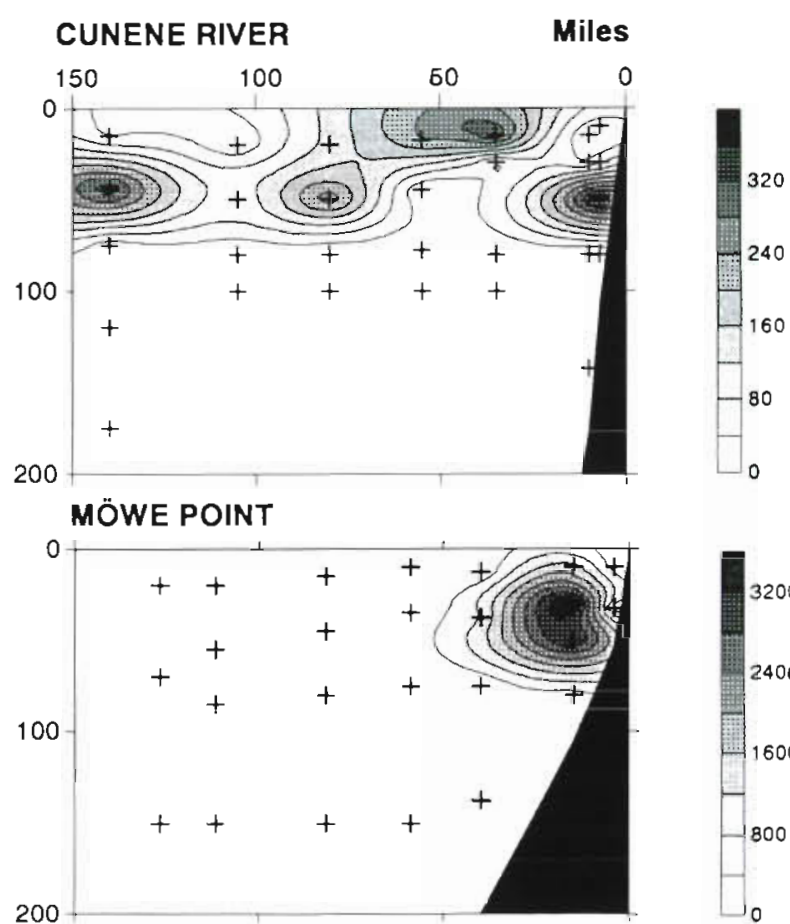

\section{WALVIS BAY}
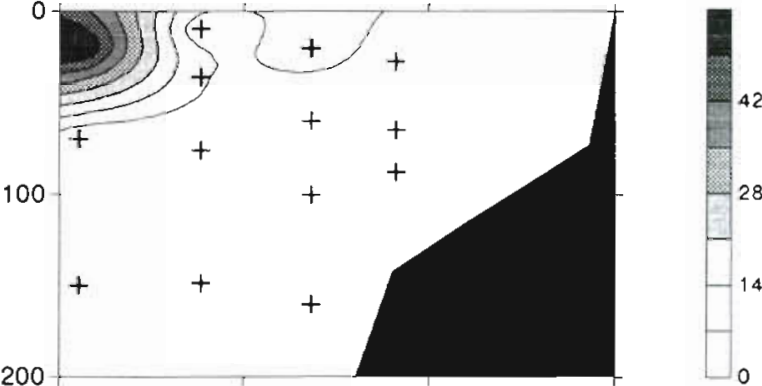

\section{LÜDERITZ}
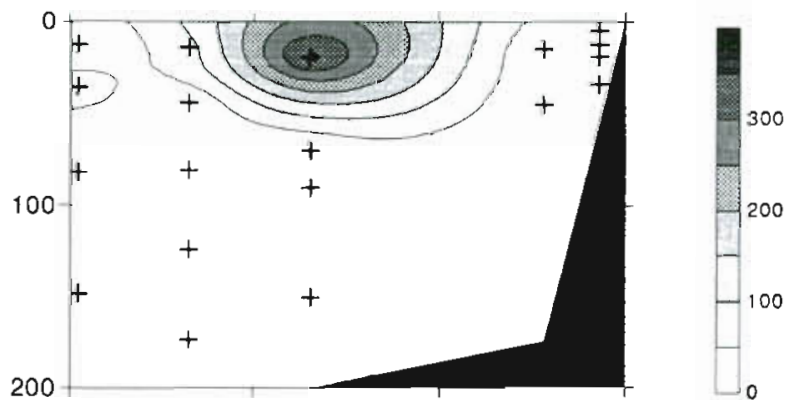

m

Fig. 13. Vertical distribution of juveniles (maturity stage I) Sagitta minima on the 4 transects sampled off the Namibian coast (ind. $1000 \mathrm{~m}^{-3}$ )

\section{Species in the southern part of the area}

Besides Sagitta setosa, which was a highly abundant species in the southern part of the study area
Sagitta tasmanica III
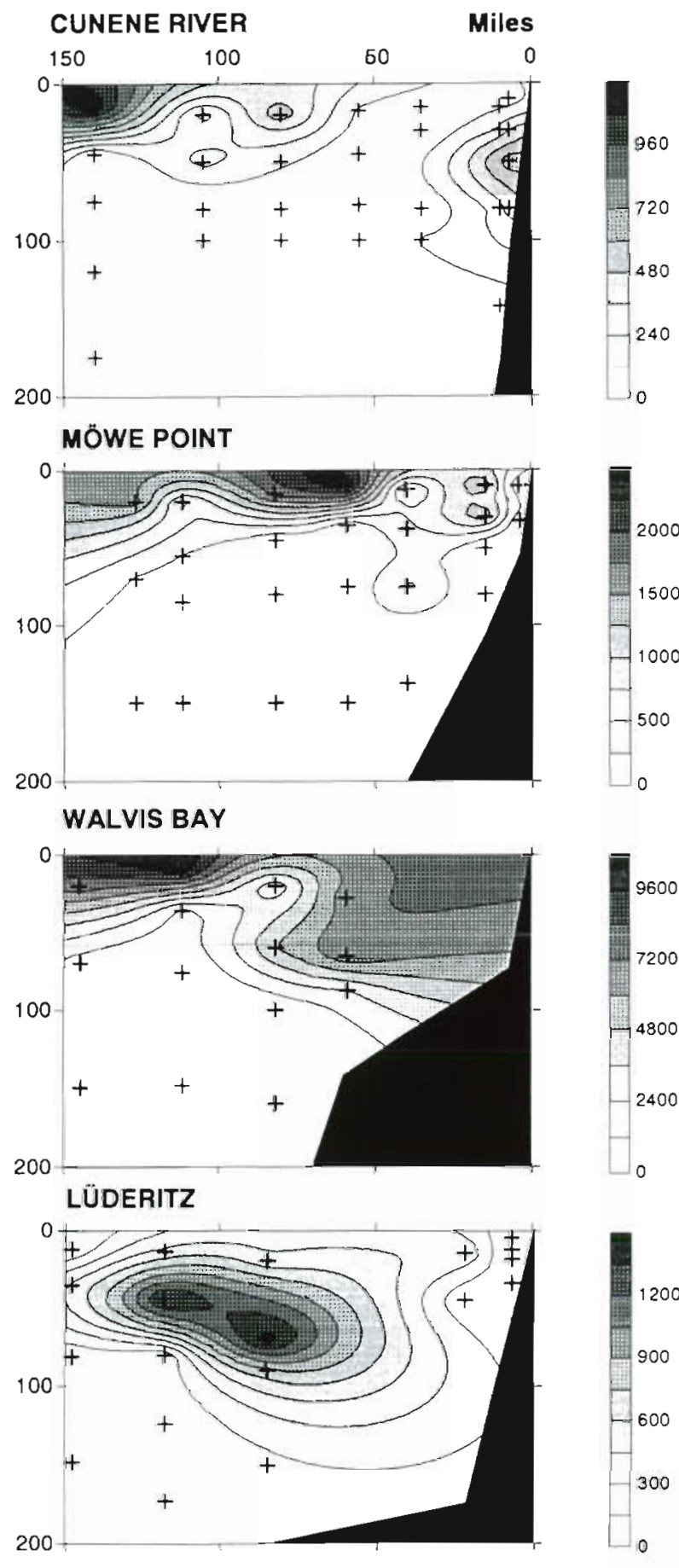

$\mathrm{m}$

Fig. 14. Vertical distribution of adult Sagitta tasmanica on the 4 transects sampled of the Namibian coast (ind. $1000 \mathrm{~m}^{-3}$ )

and the most abundant species on the survey, another 2 species were present only off Lüderitz: $S$. pacifica and $S$. maxima. Nearly all specimens collected were adults, from below the pycnocline (Table 2). 
Serratodentata Group II

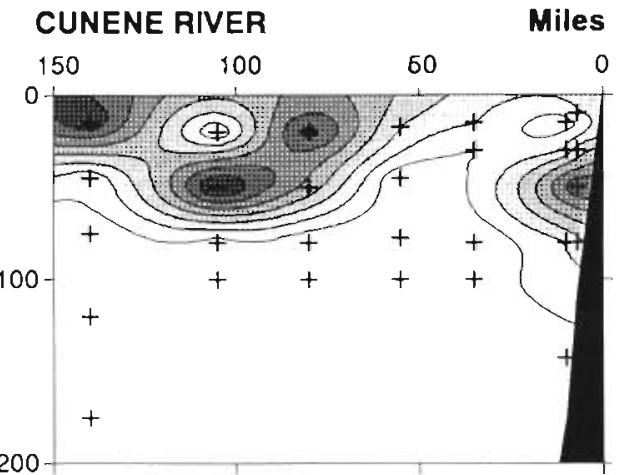

MÖWE POINT

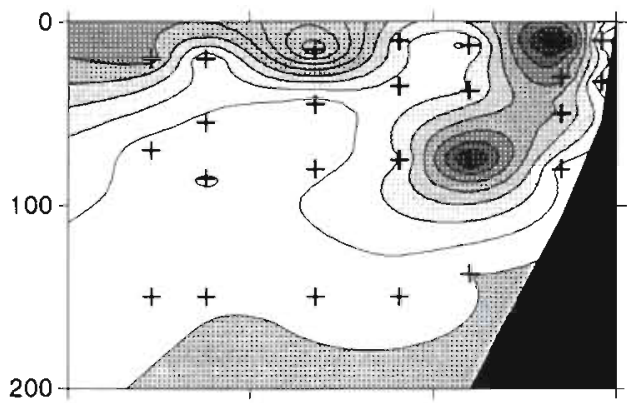

\section{WALVIS BAY}

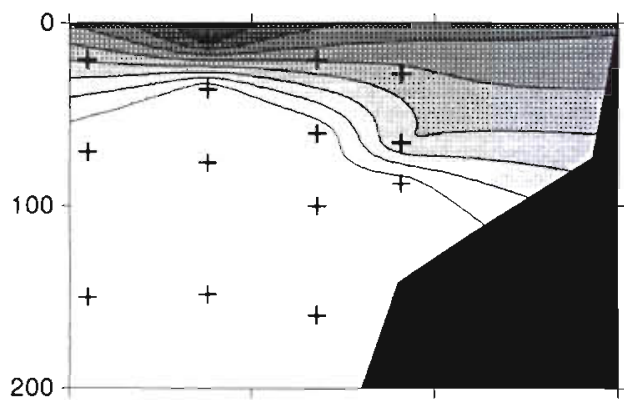

LÜDERITZ

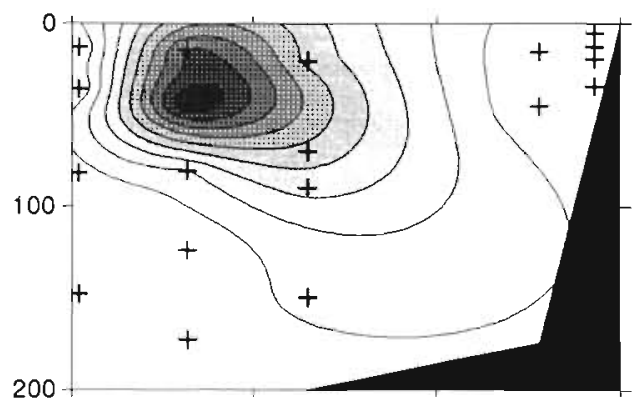

m

Fig. 15. Vertical distribution of juveniles (maturity stage II) of the Serratodentata group on the 4 transects sampled off the Namibian coast (ind. $1000 \mathrm{~m}^{-3}$ )
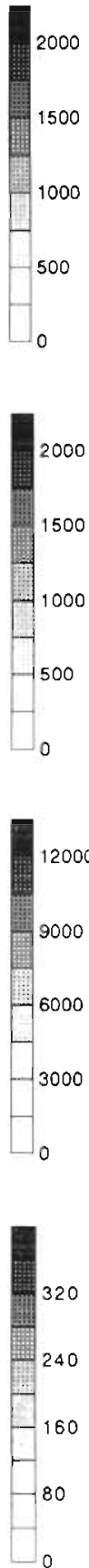

\section{DISCUSSION}

Based on all the chaetognath species collected in the northern Benguela region on a survey carried out

\section{Serratodentata Group I}

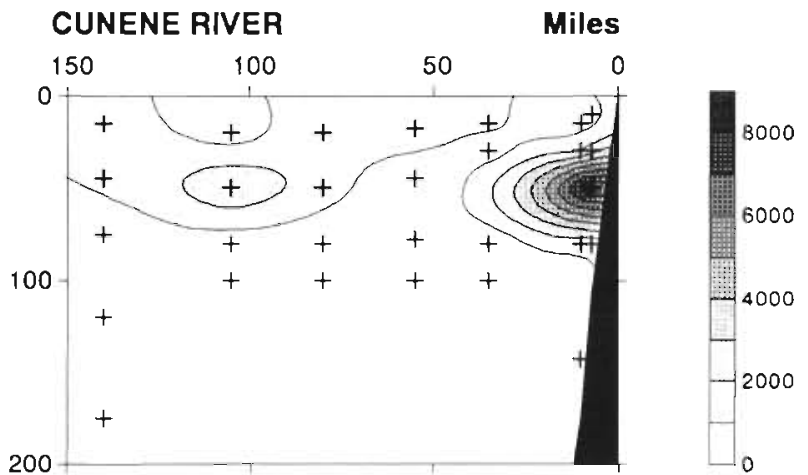

\section{MÖWE POINT}

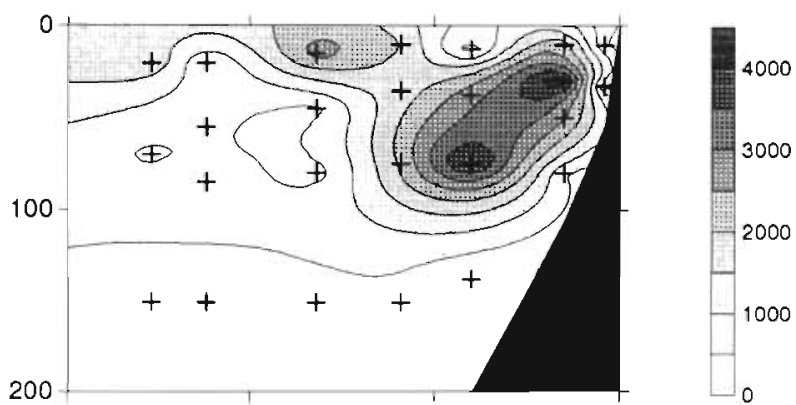

\section{WALVIS BAY}
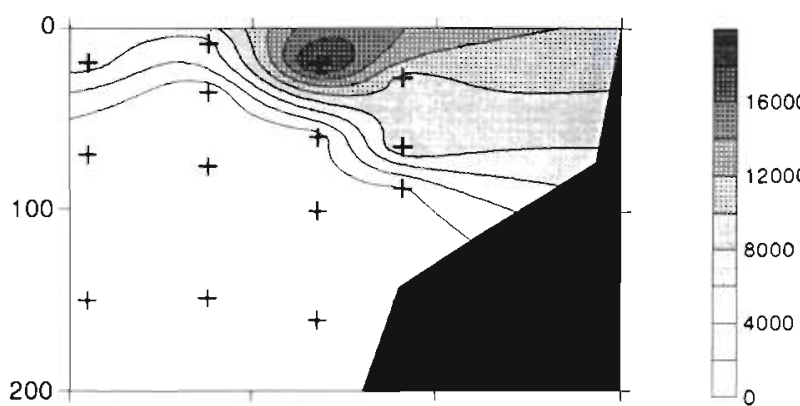

\section{LÜDERITZ}

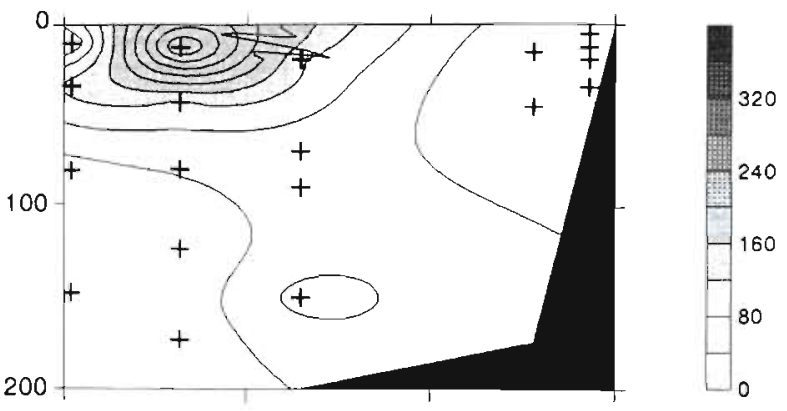

m

Fig. 16. Vertical distribution of juveniles (maturity stage I) of the Serratodentata group on the 4 transects sampled of the Namibian coast (ind. $1000 \mathrm{~m}^{-3}$ )

under conditions of abatement of upwelling, 3 general spatial distribution patterns can be identified, each closely related to the mesoscale physical structure in the area. Sagitta setosa accounted for more than $70 \%$ 

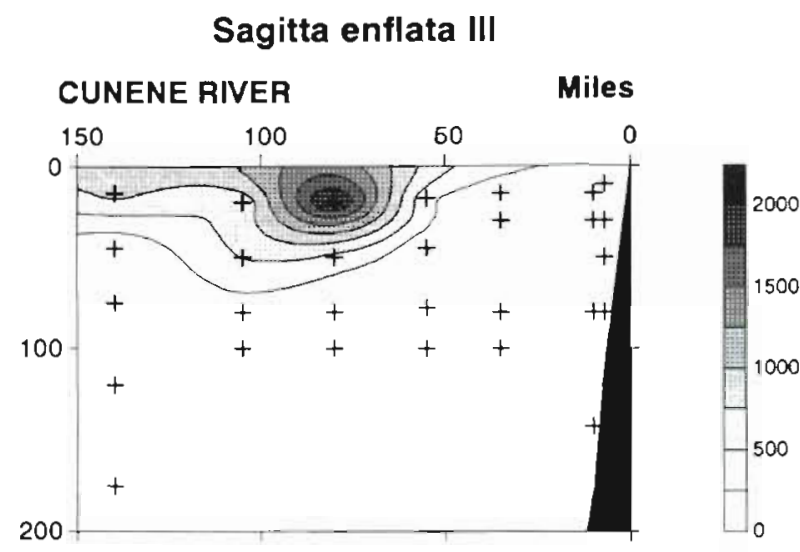

\section{MÖWE POINT}
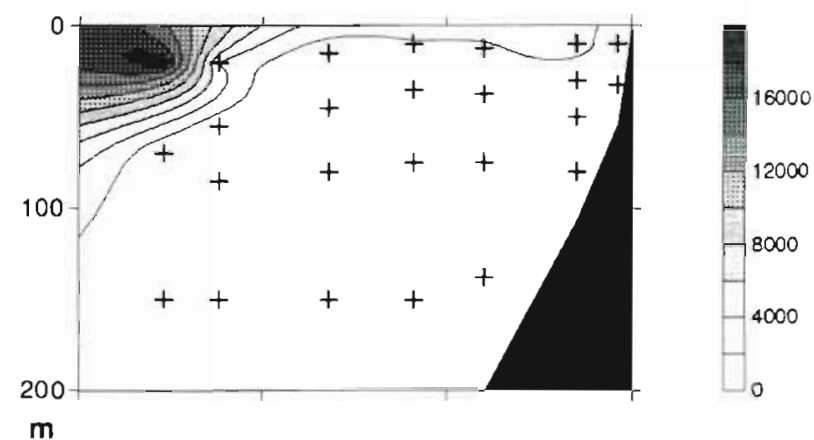

Fig. 17 Vertical distribution of adult Sagitta enflata on the 2 northern transects sampled of the Namibian coast (ind. $1000 \mathrm{~m}^{-3}$ )

of all the individuals collected. This species is difficult to differentiate from Sagitta friderici, which has been described as the most abundant species in the northern Benguela (Gibbons 1994). However, after the study of several specimens of $S$. friderici supplied by Dr Gibbons (SFRI, Cape Town), we concluded that the specimens were really $S$. setosa. Due to this confusion, we consider it difficult to compare our data with data for the southern Benguela. S. setosa seems to be adapted to upwelled water, since it was present only in cold, upwelled waters at the surface inshore. Its distribution area was more extensive in the south than in the north, because upwelling was more intense in the south. It was the only species that followed this distribution pattern, and in fact it is known as a neritic species always associated with cold water (Neto 1961, Alvarino 1965). The only exception to this species' fundamentally neritic nature was a high-density core at a depth of around $100 \mathrm{~m}$ about 60 miles $(100 \mathrm{~km})$ off Walvis Bay. That core can be related to the report by Salat et al. (1992) of upwelled water transported towards the open ocean, where it then sank and remained as a distinct water mass differentiated from the surrounding waters Besides S. setosa, certain other species, e.g. S. pacifica,

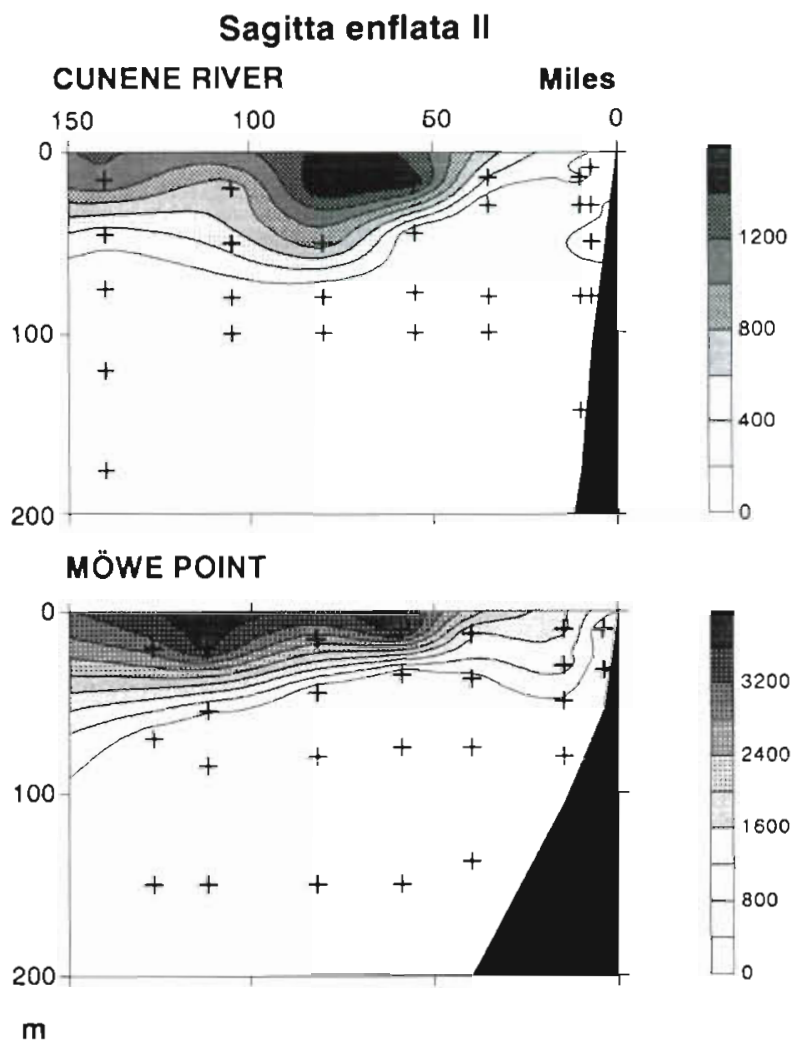

Fig. 18. Vertical distribution of juvenile (maturity stage II) Sagitta enflata on the 2 northern transects sampled off the Namibian coast (ind. $1000 \mathrm{~m}^{-3}$ )

S. decipiens, S. marri, and S planctonis, were abundant in the central part of the northern Benguela and also exhibited similar cores. An analogous phenomenon was described by Huntsman \& Barber (1977) off the northwest African coast when upwelled water was transported horizontally and later sank near the convergence zone where it continued to exist as a water mass after upwelling had abated.

High concentrations of both juvenile and adult chaetognaths were observed on the Lüderitz transect, which was located in the area of most intense upwelling. The high density values were associated with only a few species, indicative of low biodiversity. In this case Sagitta setosa was the most typical example of this phenomenon.

Another general pattern observed was the trend towards a deeper distribution in the southern half of the study area and a more surface distribution in the northern half. At the same time, the distribution tended to be more oceanic in the southern half and more inshore in the northern half. This general pattern was followed by quite a few species, including some of the most abundant species, such as Sagitta minima, S. lyra, and S. tasmanica. These 3 species are 


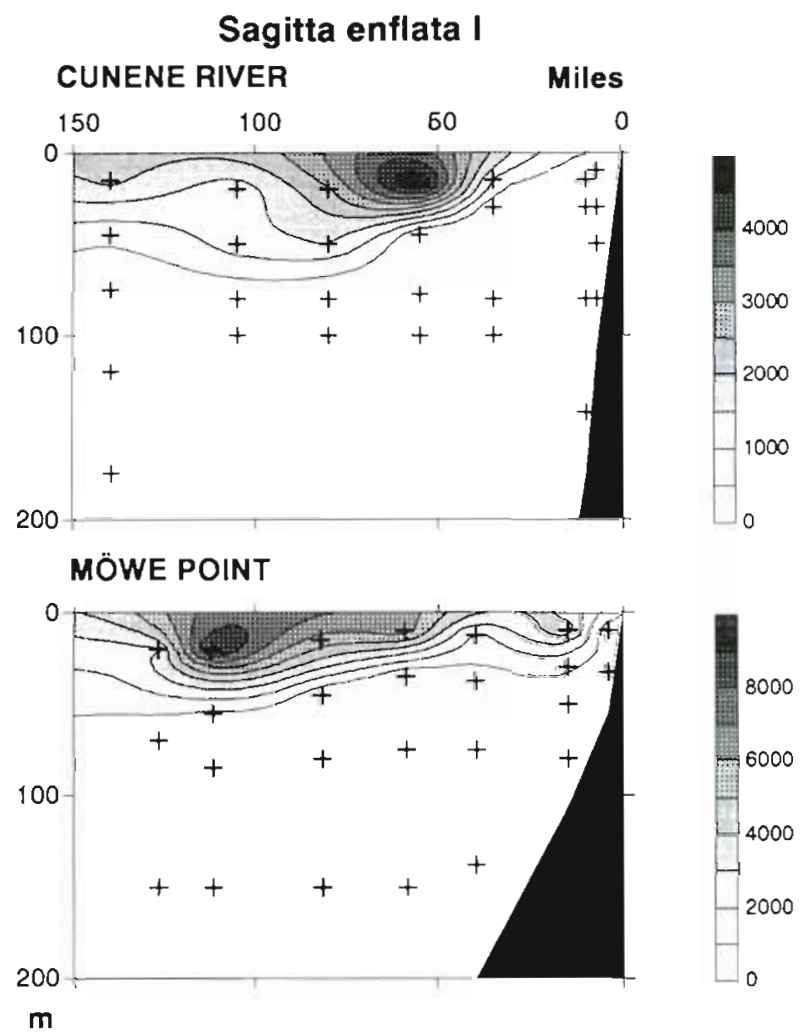

Fig. 19. Vertical distribution of juvenile (maturity stage I) Sagitta enflata on the 2 northern transects sampled of the Namibian coast (ind $1000 \mathrm{~m}^{-3}$ )

known as oceanic species in other upwelling regions as well as off the west coast of Africa (Thiriot 1978) or in the southern half of the Benguela system (Heydorn 1959, Venter 1969) where S. tasmanica accounted for nearly $70 \%$ of all the chaetognaths in waters on the oceanic side of the convergence (Venter 1969). The pattern described in the northern Benguela could be related to the distribution of SACW from the Benguela system in the region, which was pushed out of the surface layers and somewhat further of fshore in the northern half of the region as a result of the penetration by Angolan waters (Salat et al. 1992). Adaptation by chaetognaths to a given water mass is a wellknown feature of this group, to the point where they have been regarded as good indicators of different water masses (Pierrot-Bults 1982). This trend towards association with a specific water mass was clearly discernible in the distribution of adults, though juveniles presented broader boundaries to their horizontal and vertical distributions. In large measure this is because they are more vulnerable to transport by currents than adults are, though this is offset by their greater adaptability to environmental conditions (Alvariño 1965, Pierrot-Bults 1982).
Complementing the general distribution pattern described above, some species associated with SACW also exhibited high densities in certain areas offshore on the 2 northern transects in the region. For instance, the distribution of Sagitta tasmanica (Fig. 14), particularly on the Luderitz transect, indicates that there were probably 2 populations of this species in the region, a population indigenous to the northern Benguela, in keeping with the abovementioned pattern and another population that drifted into the area with the Angolan water. Juvenile $S$. tasmanica displayed a similar trend observable on the Möwe Point transect (Figs, 15 \& 16). This was a second population consisting of individuals associated with warm, mainly oceanic, Angolan waters, with a southern limit to its distribution at the front located at around 20 to $22^{\circ} \mathrm{S}$, the southward extent of the Angolan waters. This explanation of the differences in $S$. tasmanica is in accordance with the existence of 2 forms of this species (northern warmwater, southern cold-water) in the Atlantic, described by Alvariño (1969).

A third general trend was followed by the species concentrated in the northern half of the region associated with Angolan waters. Sagitta enflata, the third most abundant species on the survey, was the most important of these species. S. enflata is known as a cosmopolitan, oceanic species associated with temperate and warm waters (Alvariño 1964). It was previously reported in the study area associated with warm, oceanic water by Venter (1969), who noted that it was not particularly abundant $(<0.5 \%$ of all individuals). The different concentration levels observed on the SNEC II survey were probably a result of the strong intrusion by Angolan water that had taken place when the survey was carried out, which may have had major biological repercussions on the structure of the chaetognath community in the region comparable to the situations reported for other organisms making up the gelatinous zooplankton in the region at that time (Pagès \& Gili 1991). The important role of chaetognaths as secondary consumers could also have important repercussions on the zooplankton community as a whole. In fact, the population of only a single species in the southern Benguela, S. friderici, may consume up to $14 \%$ of daily copepod production in summer (Stuart \& Verheye 1991), $2.5 \%$ in spring (Gibbons \& Stuart 1994). The large number of chaetognath species with distributions mainly limited to the northern part of the study area (7) as opposed to those distributed exclusively in the south (2) is another relevant factor corroborating the importance of the influx of Angolan water into the northern Benguela region at the time.

The 3 general distribution patterns described above during a period of abatement of upwelling in the northern Benguela matched the mesoscale distribution 
of water masses in the region reported by O'Toole (1980). The coastal species were associated with cold, upwelled waters; the more oceanic species in the south and the more coastal species in the north were associated with SACW extending over the southern and eastern parts of the region, and the oceanic species associated with Angolan waters were present in the areas of mixed Benguela and Angolan waters of moderate temperature and salinity, considered by O'Toole (1980) to be the most oceanic waters in the region.

Adaptation of chaetognaths to specific water masses may be the main cause underlying the spatial heterogeneity observed on the SNEC II cruise. As a semigelatinous group (see Larson 1986 for definition) the chaetognaths can be compared with the gelatinous zooplankton in the study area, which presented a similar response (Pagès \& Gili 1991). On examining the spatial variation in the distribution of various species of medusae and siphonophores during periods of intense upwelling as well as during periods of abatement, Pagès (1992) observed shifts in the distribution of such species as Chrysaora hysoscella and Muggiaea atlantica, changing from a continuous, coastal distribution during upwelling to a pattern of discontinuous core populations when upwelling abated. Similar situations with regard to the spatial heterogeneity of the gelatinous zooplankton caused by changes in the level of upwelling activity have been observed in other regions of the Atlantic (Colebrook 1977, Gili et al. 1991, Pagès et al. 1991). On the other hand, other zooplanktonic groups, such as euphausiids, do not exhibit any such tendency to change their spatial distribution during the abatement of upwelling (Barange \& Pillar 1992). These workers attributed the persistent presence of euphausiids in this same area to the ability of both adults and juveniles to carry out vertical migrations, enabling them to remain in a given area within a well-defined water mass, irrespective of the depth at which it was located. This model of distribution in upwelling regions, called the 'two cells' model, was proposed by Wroblewski (1976) and later developed further by Peterson et al. (1979) in their studies on the distribution of copepods in the Oregon (USA) upwelling region. Their swimming ability (Mauchline 1980) affords euphausiids, along with such other zooplanktonic groups as copepods, greater mobility, and this suggests that there may be 2 different patterns of response to the abatement of upwelling in the region.

On the one hand, the spatial heterogeneity of the chaetognaths increases considerably, with a pronounced north-south axis of variability, as demonstrated by the PCA. On the other hand, the level of heterogeneity for crustaceans remains essentially unchanged, with the main axis of variability running inshore-offshore.
Variations in the vertical distributions and in the nychthemeral migrations of the different species are other important features observed in the northern Benguela region during the abatement of upwelling Both adults and juveniles appear to carry out more extensive migrations in the southern half of the study area than in the northern half of the area, though such migrations nearly always take place at the level of or above the pycnocline. In conjunction with this, the vertical distribution of most species was closer to the surface in the north than in the south of the area. Many of the species, and the mass abundance chaetognath species in the region overall, appeared to be concentrated preferentially at the level of or close to the pycnocline, and the distribution changed when the pycnocline changed position. Longhurst (1985) demonstrated the adaptability of different chaetognath species in the eastern Pacific Ocean, which enabled them to live within the thermocline itself. The large majority of those species exhibited very short migrations, nearly always at the level of the thermocline. Certain species present in the northern Benguela system, such as Sagitta enflata and $S$. serratodentata, carried out migrations limited to distances of no more than $20 \mathrm{~m}$ in depth and left the vicinity of the thermocline only at night. While the coexistence of many species within a small water layer could result in high levels of competition for food, Longhurst (1985) showed that there was a structure consisting of multiple sublayers that made habitat partitioning possible. A similar structure was proposed for phytoplankton distribution by Margalef (1978b). This small-scale distribution of the plankton, both prey as well as possible predators, enables species to exploit a turbulent, highenergy habitat like the thermocline, by adopting separate vertical distributions confined to highly specific layers (Longhurst 1985).

The marked ability of chaetognaths to adapt to zones of high turbulence, e.g. the pycnocline and areas of permanent upwelling along the coast of Namibia, explains why their vertical and horizontal distributions change as the distribution of physical structures changes when upwelling abates. The adaptability of the zooplankton to such high-energy areas has recently been reported in other areas such as the subarctic Pacific (Mackas et al. 1993) and the northern Pacific (Haury et al. 1990). Those workers have provided a general picture of how the different species adapt to special conditions of mixing and turbulence, which in turn regulates their vertical distribution in the water column.

In conclusion, the abatement of upwelling in the northern Benguela region brings about changes in both the horizontal and vertical hydrographic structure These variations in turn bring about important changes 
in the spatial distribution of chaetognaths, by shifting the orientation of the axis of maximum variability from inshore-offshore during active upwelling to a latitudinal direction. To a large extent this is because changes in the location of the pycnocline and in the intensity of the activity of the upwelling centres make the vertica] axis of variability more important than the inshoreoffshore axis. The adaptability of chaetognaths, which enables them to dwell in turbulent, high-energy habitats such as the pycnocline layer, causes their horizontal and vertical distributions and their migrations to adapt to the location and width of the pycnocline.

Acknowledgements. We thank Dr P. Martin for her help with the statistical programs and Mr R. B. Sacks for his help in preparing the English version. We also thank Dr Gibbons for supplying some specimens from South Africa and Dr P. Andreu, Dr J. P. Casanova and Dr A. C. Pierrot-Bults for reviewing some of the samples and confirming that the identified species was Sagitta setosa rather than $S$ friderici. We dre grateful to 3 anonymous referees for their valuable comments on the manuscript. This research was supported by a grant provided by the Comissió lnterdepartamental de Recerca i Innovació Tecnològica (CIRIT) of the Regional Government of Catalonia

\section{LITERATURE CITED}

Alvariño A (1964) Bathymetric distribution of chaetognaths. Pacif Sci 18:64-82

Alvarno A (1965) Chaetognaths. Oceanogr Mar Biol A Rev 3 $115-194$

Alvariño A (1969) Los Quetognatos del Atlántico. Distribución y notas esenciales de sistemática. Trab Inst Esp Oceanogr $37: 1-290$

Barange M (1990) Vertical migration and habitat partitioning of six euphausiid species in the northern Benguela upwelling system. J Plankton Res 12:1223-1237

Barange M, Pillar SC (1992) Cross-shelf circulation, zonation and maintenance mechanisms of Nyctiphanes capensis and Euphausia hanseni (Euphausiacea) in the northern Benguela upwelling system. Cont Shelf Res 12:1027-1042

Barber RT, Smith RL (1981) Coastal upwelling ecosystems. In: Longhurst AR (ed) Analysis of marine ecosystems. Academic Press, London, p 31-68

Boyd AJ, Agenbag JJ (1985) Seasonal trends in the longshore distribution of surface temperatures off southwestern Africa, $18-34^{\circ} \mathrm{S}$, and their relation to surface conditions and currents in the area $21-24^{\circ} \mathrm{S}$. In: Bas C, Margalef R, Rubies $\mathrm{P}$ (eds) International symposium on the most important upwelling areas off western Africa (Cape Blanco and Benguela), Vol 1. Instituto de Investigaciones Pesqueras, Barcelona, p 119-14.8

Boyd AJ, Salat J, Mlasó M (1987) The seasonal intrusion of relatively saline water on the shelf off northern and central Namibla. S Afr J Mar Sci 5:107-120

Colebrook JM (1977) Annual fluctuations in biomass of taxonomic groups of zooplankton in the California Current, 1955-59. Fish Bull US 75(2):357-368

Gibbons M.J (1994) Diel vertical migration and feeding of Sagitta fridericl and Sagitta tasmanica in the southern Benguela upwelling region, with a comment on the struc- ture of the guild of primary carnivores. Mar Ecol Prog Ser 111:225-240

Gibbons MJ, Stuart $\vee(1994)$ Feeding and vertical migration of the Chaetognatha Sagitta friderici (Ritter-Zahony 1911) in the southern Benguela during spring 1987, with notes on seasonal variability of feeding ecology. S Afr J Mar Sci $14: 361-372$

Gili JM, Pagès F, Fusté X (1991) Mesoscale coupling between spatial distribution of planktonic cnidarians and hydrographic features along the Galician coast (northwestern Iberian Peninsula). Scient Mar 55:35-42

Grant GC (1967) The geographic distribution and taxonomic variation of Sagitta serratodentata Krohn 1853 and Sagitta tasmanica Thomson 1947 in the North Atlantic ocean. PhD thesis, University of Rhode Island, Providence

Haury LR, Yamazaki $H_{1}$ ltsweire EC (1990) Effects of turbulence shear flow on zooplankton distribution. Deep Sea Res 37:447-461

Heydorn AEF (1959) The chaetognatha off the west coast of the union of South Africa. Investl Rep Div Fish Un S Afr 36 $1-56$

Huntsman SA, Barber RT (1977) Primary production of northwest Africa: the relationship to wind and nutrient conditions. Deep Sea Res 24:25-34

Hutchings L (1981) The formation of plankton patches in the Southern Benguela Current. In: Richards FA (ed) Coastal and estuarine sciences 1 Coastal upwelling. American Geophysical Union, Washington, DC, p 496-506

Larson RJ (1986) Water content, organic content, and carbon and nitrogen composition of medusae from the northeast Pacific. J Exp Mar Biol Ecol 99:107-120

Longhurst AR (1985) Relatıonshıp between diversity and vertical structure of the upper ocean. Deep Sea Res 32 $1535-1570$

Mackas DL, Sefton H, Miller CB, Raıch A (1993) Vertical hahitat partitioning by large calanoid copepods in the oceanic subarctic Pacific during spring. Prog Oceanogr 32 259-294

Madhupratap M. Sreekumaran Nair SR, Haridas P, Padmavati $G$ (1990) Response of zooplankton to physical changes in the environment: coastal upwelling along the central west coast of India. J Coast Res 6:413-426

Margalef R (1978a) What is an upwelling ecosystem? ln: Boje $R$, Tomczak $M$ (eds) Upwelling ecosystems. SpringerVerlag, Berlin, p 12-14

Margalef R (1978b) Life-forms of phytoplankton as survival alternatives in an unstable environment. Oceanol Acta 1. 493-509

Mauchline J (1980) The biology of mysids and euphausinds. Adv Mar Biol 7:1-681

Neto TS (1961) Quetognatas dos mares de Angola. Estudos de biologia Marítima. Mem Junta Invest Ultramar (Port) Ser $2(29): 1-60$

Olivar MP, Barange M (1990) Zooplankton of the northern Benguela region in a quiescent upwelling period. J Plankton Res 12:1023-1044

O'Toole MJ (1980) Seasonal distribution of temperate and salinity in the surface waters off South West Africa, 1972-1974. Investl Rep Sea Fish Res Inst S Afr 121:1-25

Pagès F (1992) Mesoscale coupling between planktonic cnidarians distribution and water masses during a temporal transition between active upwelling and abatement in the northern Benguela system. S Afr J Mar Sci 12:41-52

Pagès F, Gili JM (1991) Effects of large-scale advective processes on gelatinous zooplankton populations in the northern Benguela ecosystem. Mar Ecol Prog Ser 75: 205-215 
Pagès F, Verheye HM, Gili JM, Flos J (1991) Short-term effects of coastal upwelling and wind reversals on epiplanktonic cnidarians in the southern Benguela ecosystem. S Afr J Mar Sci 10:203-211

Pearre S (1973) Vertical migration and feeding in Sagitta elegans Verrill. Ecology 54:300-313

Peterson WT, Miller CB, Hutchinson A (1979) Zonation and maintenance of copepod populations in the Oregon upwelling zone. Deep Sea Res 26A: 467-494

Pierrot-Bults AC (1982) Vertical distribution of Chaetognatha in the central northwest Atlantıc near Bermuda. Biol Oceanogr 2:31-60

Salat J, Masó M, Boyd AJ (1992) Water mass distribution and geostrophic circulation off Namibia during April 1986 Cont Shelf Res 12:355-366

Shannon LV (1985) The Benguela ecosystem. Part I. Evolution of the Benguela, physical features and processes. Oceanogr Mar Biol A Rev 23:105-182

Shannon LV, Boyd AL, Brundrit GB, Tauton-Clark J (1986) On the existence of an El Nino-type phenomenon in the

This article was submitted to the editor
Benguela system. J Mar Res 44:495-520

Shannon LV, Pillar SC (1986) The Benguela ecosystem. Part III. Zooplankton. Oceanogr Mar Biol A Rev 24:65-170

Stuart V, Verheye HM (1991) Diel migration and feeding patterns of the chaetognath, Sagitta fridernci, off the west coast of South Africa. J Mar Res 49:493-515

Thiriot A (1978) Zooplankton communities in the West African upwelling area. In: Boje R, Tomczak $M$ (eds) Upwelling ecosystems. Springer-Verlag, Berlin, p 32-61

Venter GE (1969) The distribution of some chaetognaths and their relation to hydrographical conditions, with special reference to the south west African region of the Benguela current. Investl Rep Div Sea Fish S Afr 16:1-73

Wroblewski JS (1976) A model of the spatial structure and productivity of phytoplankton populations during variable upwelling of the coast of Oregon. PhD thesis, Florida State University, Tallahassee

Zo Z (1973) Breeding and growth of the chaetognath Sagitta elegans in the Bedford Basin. Limnol Oceanogr 18: $750-756$

Manuscript first received: January 22, 1996

Revised version accepted: May 13, 1996 